\title{
Innovativeness contested -
} discrepancies between managerial ideals and employee identities

Outi Vanharanta 


\section{Innovativeness contested - discrepancies between managerial ideals and employee identities}

\section{Outi Vanharanta}


Supervising professor

Professor Henri Schildt, Aalto School of Business, Finland

Thesis advisor

Assistant Professor, Tea Lempiälä, University of California, Merced, USA

\section{Preliminary examiners}

Adjunct Professor, Pikka-Maaria Laine, University of Lapland

Professor André Spicer, Cass Business School, United Kingdom

\section{Opponent}

Professor André Spicer, Cass Business School, United Kingdom

DOCTORAL DISSERTATIONS 39/2019

(C) 2019 Outi Vanharanta

ISBN 978-952-60-8441-1 (printed)

ISBN 978-952-60-8442-8 (pdf)

ISSN 1799-4934 (printed)

ISSN 1799-4942 (pdf)

http://urn.fi/URN:ISBN:978-952-60-8442-8

Unigrafia Oy

Helsinki 2019

Finland 
Author

Outi Vanharanta

Name of the doctoral dissertation

Innovativeness contested - discrepancies between managerial ideals and employee identities

\begin{tabular}{l}
\hline Publisher School of Business \\
\hline Unit Department of Management Studies \\
\hline Series Aalto University publication series DOCTORAL DISSERTATIONS 39/2019 \\
\hline Field of research Organization and Management \\
\hline Date of the defence 22 March 2019 \\
\hline Language English $\quad \square$ Article dissertation \\
$\square$ Monograph
\end{tabular}

Abstract

In the contemporary discourse of innovation, every organizational member is constructed as a potential innovator who is expected to contribute creative outputs for the benefit of the organization. This drives organizations to introduce structures and procedures through which the creative potential of employees can be most efficiently utilized. Earlier research has studied extensively organizational antecedents for innovativeness, however, studies discussing employee responses concerning managerial efforts to increase innovativeness have been less explored.

This study complements earlier work on innovation by exploring the ways in which managers seek to enhance innovativeness and justify these methods, as well as how employees respond to these efforts. This micro-level investigation of the processes through which innovativeness is constructed unveils its controversial nature in organizations. Drawing on empirical data from managerial efforts to increase innovativeness in six large Finnish organizations, the study unveils the subtle forms of resistance resulting from identity struggles and the plurality of meanings concerning innovativeness held by organizational actors. The thesis is comprised of four empirical sub-studies that illuminate this phenomenon from different perspectives. The empirical material is comprised of altogether 112 interviews with managers and employees, and 49 hours of nonparticipant observation in company premises.

The analysis of the study focuses on the discursive construction of organizational efforts to increase innovativeness and particularly the ways in which the innovative subjectivity is constructed in the managerial discourse. In addition, the study explores how employees respond to the managerial efforts to increase employee innovativeness. The study illuminates the discrepancies between the managerial ideals of innovative subjectivity and the ways in which employees identify themselves with innovativeness. The results show, how the managerial efforts to increase innovativeness are contested by employees and may have counter-productive influence on employee identification with organizational innovation pursuits. Managerial efforts driven by abstract notions such as creative freedom, encounters, collaboration, proactivity and future orientation resulted in alienation from the organizational innovation pursuits by employees. Moreover, the study illustrates how the fluidity and ambiguous nature of the concept of innovativeness enables organizational actors to position themselves within the discourse in a multiplicity of ways in different organizational contexts.

Keywords Innovativeness, resistance, subjectivity, identity, discourse

\begin{tabular}{lc}
\hline ISBN (printed) $978-952-60-8441-1$ & ISBN (pdf) $978-952-60-8442-8$ \\
\hline ISSN (printed) $1799-4934$ & ISSN (pdf) $1799-4942$ \\
\hline Location of publisher Helsinki & Location of printing Helsinki Year 2019 \\
\hline Pages 143 & urn http://urn.fi/URN:ISBN:978-952-60-8442-8 \\
\hline
\end{tabular}





\section{Acknowledgements}

I would like to express my gratitude to everyone involved in my dissertation process. I am most indebted to Professor Henri Schildt, who had an important role as my supervisor during the last year of the process. Thank you for your encouraging words and for helping me weave together the storyline of this dissertation.

Assistant Professor Tea Lempiälä, without your encouragement I would never had embarked in PhD studies. Thank you for the inspiring writing processes, insightful discussions and all the support in the form of supervision, friendship and persuasion that pushed me forward.

Professor Raimo Lovio, I am deeply grateful for your encouragement to apply for the PhD program at Aalto School of Business and your reassuring support during the first years of my studies.

I wish to express my appreciation to the pre-examiners of my thesis, Professor André Spicer and Professor Pikka-Maaria Laine, for taking the time to review the manuscript. I further wish to express my warmest thanks to Professor Spicer for also acting as my opponent.

I would like to thank my former and current colleagues at Aalto University School of Science, particularly Jaana Näsänen, Tuomo Eloranta and Professor Matti Vartiainen. Jaana, it has been a great pleasure to co-author with you and share the dissertation process with you from the very beginning. Your professional insight, support, advice and friendship throughout the years have been invaluable. Tuomo, I am very grateful for having such a considerate, insightful and efficient colleague. The last year would have been a disaster without your help and collaboration! Matti, thank you for being such a patient superior in research projects, and providing encouragement during the critical final stretches of the process.

I would also like to express my warmest thanks to "IMI folks", the management Pekka Berg and Jussi Pihlajamaa, and the rest of the team, Matti Pihlajamaa (thank you for your comments to Article II!), Kirsi Polvinen (thank you for keeping up the spirit!), J-P Kevätsalo, Sanni Tiitinen, Hani Tarabichi, Ansko Patana and Laura Kanto.

I am grateful to the whole DIEM department for letting me skulk in the prestigious fourth floor of Tuas. I am particularly thankful to my PhD student peers Robert van der Have (thanks for the competition!) and Rúben Vicente Saéz (thanks for bringing us sunrays from Spain!). Suvi Niemelä, Maria Tikka, Paula 
Salminen, Mary-Ann Alfthan, warm thanks for all help and collaboration in projects and for making my stay at DIEM pleasant and smooth.

I would also like to thank Professor Miia Martinsuo for her insightful comments on Article IV and encouragement to dig into the world of project management research, and the whole FutIS WP2-team for input in the roundtable sessions where articles in progress were discussed.

In 2015, I had the pleasure of visiting Kozmetzky Global Collaboratory at Stanford University to focus on developing and writing the first article. Bhavna Hariharan, Sayed Shariq and Prachee Jain, thank you for welcoming me to your unique community, introducing your influential work in addressing global challenges, and helping me in deepening my thinking on organizational paradoxes and innovation.

I am also deeply grateful to the individuals in the companies who took part in the research projects during which the empirical material for this thesis was generated.

A number of funding agencies have supported this work, including the Finnish Work Environmet Fund, the Emil Aaltonen Foundation, the Support Fund of Aalto Business School, the Foundation for Economic Education, and the Wallenberg Foundation. I am also deeply grateful for funding from the Department of Organization Studies at Aalto Business School, which enabled the last sprint during the process.

Heartfelt thanks go to my family, mum, dad, Sakari, Mari and Lauri for the subtle enquiries about the progress of my "writing projects" and all the invaluable help and support in managing the work-life balance. Riitta and Jorma, one could not hope for more supporting in-laws and dedicated grandparents for the girls.

Mikko, Vilja and Varpu, your love and support, and the joy and laughter we share, are the most important things in life.

Helsinki, 16 January, 2019

Outi Vanharanta 


\section{Contents}

Acknowledgements ............................................................................ 1

List of Publications ..................................................................................... 5

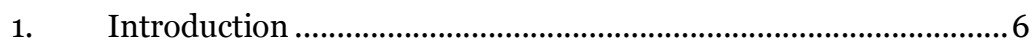

1.1 Research focus and research questions ................................... 10

1.2 The structure of the thesis ......................................................11

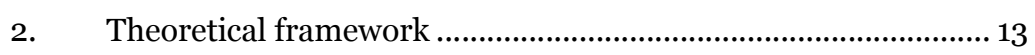

2.1 Discursive approach to organizational analysis....................... 13

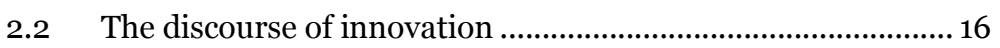

2.3 Subjectification as a form of organizational control................. 18

$2.4 \quad$ Resisting identity regulation ......................................................22

2.5 Summary of the theoretical framework....................................25

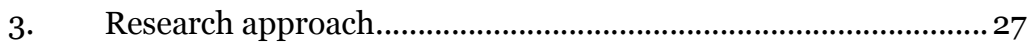

3.1 Methodological foundations...................................................... 27

3.2 The context of the study...........................................................28

3.3 Data generation and methods of analysis ................................. 31

3.3.1 Data generation methods...................................................... 31

3.3.2 Analytical approaches ........................................................ 32

3.3.3 Researcher's role in the research process ..............................34

4. Article summaries and results ........................................................ 37

4.1 Article I: Rethinking the Control-Freedom Paradox ................ 37

4.2 Article II: Competing narratives of suggestion system change38

4.3 Article III: Contradictory argumentations of spatial change..40

4.4 Article IV: Program group's construction of context................42

4.5 Summary of the results.............................................................4 43

4.5.1 Construction of the innovative subject .................................. 43

4.5.2 Responses to subjectification ..............................................4 45

4.5.3 Pragmatic consequences.......................................................46

5. Discussion ....................................................................................49

5.1 The multifaceted discourse of innovation ...............................49 
$5.2 \quad$ Regulating innovative identities ............................................ 52

5.3 Resisting the managerial ideal of innovative subjectivity....... 54

5.4 Practical contributions ........................................................57

5.5 Limitations of the study and future research directions ..........58

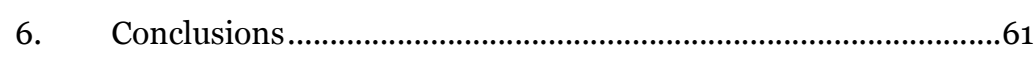

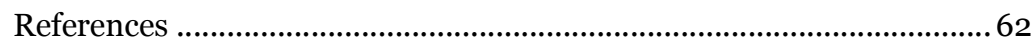

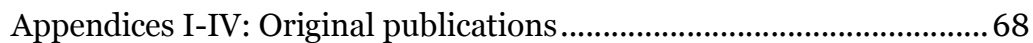




\section{List of Publications}

This doctoral thesis consists of a summary and of the following publications, which I refer to in the text by their Roman numerals:

I. Lempiälä, T., \& Vanharanta, O. (2018). Rethinking the Control-Freedom Paradox in Innovation: Toward a Multifaceted Understanding of Creative Freedom. The Journal of Applied Behavioral Science, 54(1), 62-87. https://doi.org/10.1177/0021886317727458.

II. Vanharanta, O. (2018). Whose responsibility is it anyway? Competing narratives of suggestion system change. Creativity \& Innovation Management, 27(3), 244-254. https://doi.org/10.1111/caim.12286.

III. Näsänen, J., \& Vanharanta, O. (2017). Managers' and employees' contradictory argumentations of spatial change. Journal of Organizational Change Management, 30(6), 844-857. https://doi.org/10.1108/JOCM-012017-0021.

IV. Näsänen, J., \& Vanharanta, O. (2016). Program group's discursive construction of context: A means to legitimize buck-passing. International Journal of Project Management, 34(8), 1672-1686. https://doi.org/10.1016/j.ijproman.2016.09.008. 


\section{Introduction}

While innovativeness is constructed in the present-day discourse as an essential feature of individuals, organizations and societies, innovation and innovativeness have not always been highly regarded. The term innovation entered the common discourse in the 1400 , when it was used to name heretical practitioners of religion (Godin, 2012). Innovation was essentially constructed as a negative concept and the term innovator was used as an accusation. An innovator was someone who would rupture the current values of the society. After the French revolution in Europe, the concept came to be equated with political revolutions and revolutionaries (Godin, 2012; 2015). This fed to the association of innovation as sudden and violent, and the consequences of innovation were used to argue against change. Innovating was seen as introducing change to the established order and was explicitly forbidden by law. Only in the late 19th century did the term innovation become gradually associated with creativity as the pejorative meaning shifted towards positive connotations of novelty and productivity (Fourége \& Harding, 2012; Godin, 2012). While nnovation was for a long period associated primarily with artistic endeavors, in the 2oth century, it became associated with technological development and in the 1960's technology became recognized as the key to economic progress (Godin, 2012; 2015; Fourége \& Harding, 2012). Resulting from this, innovation became a measurable construct through which national progress could be monitored (Fourége \& Harding, 2012). Today, innovation continues to be associated with revolution and radical shifts in the contemporary customs (Hamel \& Ruben, 2000), however, it has a strongly positive connotation as creating opportunities for wealth and prosperity.

The notion that innovativeness is an indispensable attribute for nations, organizations and even the individual is well established in the discourse of contemporary societies. At the societal level, innovativeness is constructed as one of the key drivers of economic growth, which leads to national wealth and prosperity (e.g. Freeman, 1995; Nelson, 1993). At the heart of innovative societies are its firms, for which innovativeness is constructed as a prerequisite for survival because of the unpredictable and rapidly changing nature of the operative environment, which necessitates the capacity for fast renewal. Thus, innovation has become a central focus area of strategic development in organizations (e.g. Abernathy \& Clark, 1985). Concepts associated with innovativeness, such as agility, risk-taking and adaptation, are central virtues of modern organizations, 
and have become norms that all organizations-regardless of industry-are expected to pursue. Organizations seek to enhance their innovative potential through the creation of structured innovation processes and by implementing practices that are expected to increase employee innovative behavior. Personnel are viewed as a reservoir of ideas and knowledge that belong to the organization (Garud \& Nayyar, 1994), and by implementing the optimal methods, organizations seek to exploit this resource to the full. Every organizational member is constructed as a potential innovator who is expected to contribute creative outputs for the benefit of the organization (Hasu et al, 2012).

Innovativeness ${ }^{1}$ is conventionally treated as an objective feature of organizations and individuals. The pursuit towards innovativeness cuts across all societal levels and has become a noncontroversial practice remaining widely accepted and unquestioned (e.g. Anderson et al, 2014; Gripenberg et al, 2012). Moreover, approaches that challenge the established innovation paradigm are rarely presented, and the imagery associated with the concept of innovativeness is almost exclusively positive (Godin, 2012). While during the last decades some criticism towards the dominant innovation paradigm has indeed been presented (see e.g. Anderson, 2014; Sveiby et al, 2012; Kimberly, 1981), this work has been left to the margins.

Following the constructionist paradigm, it can be established that the articulation of innovativeness as undisputedly positive and essential for the success of nations, organizations and individuals alike, has become dominant-in Foucault's terms, naturalized (Foucault, 1977). Thus, innovativeness can be argued as having a hegemonic status in the Western society (Fougére \& Harding, 2012). Following Fleming and Spicer (2014), this means that particular ideological values dominate the discourse creating shared assumptions, ideals and collective rules. Ideology refers to a relatively coherent set of assumptions, beliefs, and values about a particular part of social reality, which legitimates action, and explains and justifies social order (Berger \& Luckmann, 1966; Alvesson, 1991). By reproducing the ideology, the dominant innovation discourse legitimates organizational practices, which seek to transform individuals into particular kinds of innovative subjects.

Practically oriented fields of social science, such as management, have been criticized for reproducing ideologies by attending to the current interests of powerful managers and funding institutions, and because these fields fail to engage in reflexive examination of the underlying assumptions and values they build upon (e.g. Ogbor, 2000). Critical organizational scholars have sought to dispel and deconstruct such dominant discourses in the context of various management disciplines and unveil the processes through which these legitimize organizational structures and ways of behaving and create power relations that

\footnotetext{
${ }^{1}$ In literature, innovativeness is sometimes used to refer to a degree of novelty of an idea or a product (Garcia \& Calantone, 2002), whereas in the present study the purpose is to understand how innovativeness is constructed as an attribute of organizations, teams and individuals (see e.g. Anderson et al, 2014; Huhtala et al, 2007). Following the integrative definition of creativity and innovation by Anderson et al (2014), the discourse of innovation is, in this study, considered as a broader discourse which includes the definition of innovativeness-i.e. the ability to produce innovations.
} 
become normal and obvious. For example, Knights and Morgan (1991) discussed how the strategy discourse constitutes particular managerial and labor subjectivities that enhance the productive power of organizations through locking individuals and groups into their tasks and commitments. The strategy discourse empowers managers by constructing them as "strategic actors" who can make a difference while acting on the behalf of the organization and simultaneously giving them a legitimate and meaningful role. In a similar vein, Ogbor (2000) examined the entrepreneurship discourse to illustrate its discriminatory, gender biased and ideologically controlled nature. Deconstructions of dominant discourses have been carried out in various other domains as well, including human resource management (Townley, 1993), management accounting systems (Ezzamel and Willmott, 1998) and project management (Hodgson, 2002; Clegg et al. 2002). These studies have illuminated how the domination of a particular discourse naturalizes an extant social order, which is reproduced in the formulation of research goals of scientists as well as in the various forms of organizational structures and practices imposed on organizational actors.

Critical organizational scholarship has explored organization-level local discourses to investigate how culturally dominant discourses are reproduced in organizational talk. While the culturally available dominant discourses form the conditions and resources for the actual spoken interchanges between people (Fairclough, 1992), focus on situated language use acknowledges the role of locally negotiated meanings in constructing the social reality of organizations (Hardy \& Thomas, 2014). This means that organizational actors have agency to construct their own alternative reality, although always shaped by the available social discourses (Bergström \& Knights, 2006; Burr, 2015; Humphreys \& Brown, 2002; Kovalesci et al, 2006; Samra-Fredericks, 2003; Segercrantz, 2012). Thus, the process through which discourses operate in organizations can be viewed as an "ongoing battle over power, hegemony and individualized sense of subjectivity” (Laine \& Vaara, 2007: 7).

While managerial discourses seek to introduce particular subjectivities for organizational actors, these may be resisted through alternative discursive articulations. As suggested by Elsbach (1999), the ways in which individuals identify with the managerially promoted organizational discourse can take multiple forms including identification, neutral identification, dis-identification and schizo-identification. As a result, the interplay of managerial discourse and individual identity narratives generates interesting dynamics in, for example, development pursuits in organizations, as organizational actors, may initiate discourses that diverge from those of top management and are better aligned with their own identities. Through this, employees may create "room for maneuver" for themselves and legitimate actions that run counter to the managerial plans (Laine \& Vaara, 2007). Struggles between the subjectivities imposed by the hegemonic discourse and individual identity processes become manifest in different forms of micro politics of resistance (Thomas \& Davies, 2005). Such identity struggles and processes of resistance towards the managerial hegemony have been reported, for example, in the context of the implementation of new public 
management (Thomas \& Davies, 2005; Halford \& Leonard, 2005), total quality management (Knights \& McCabe, 2000) and changes in organizational strategy (Laine \& Vaara, 2007).

In a similar vein, scrutinizing the discourse of innovation from the critical perspective can provide much value in understanding processes of subjectification, identity struggles and power relations related to the practice of innovation in organizations. At the organizational level, the discourse is reproduced in the organizational structures and practices as well as managerial rhetoric through which organizations seek to stimulate innovative behavior among employees. The institutionalized innovation discourse serves as a legitimate repertoire from which managers may draw while promoting a particular form of organizational innovativeness for consumption by employees, which entails the introduction of particular subject positions for organizational actors.

The present study investigates how the innovation discourse is reproduced in the organizational context by exploring the ways in which managers seek to enhance innovativeness and justify these methods, and how employees respond to these efforts. A particular focus is on the subjectivities that are constructed in the managerial discourse and the ways in which employees relate to these in their accounts. Exploring innovativeness as socially constructed directs attention to the discursive processes, which produce a particular version of innovativeness as the shared "truth", constructing subject positions and thus having power implications as well as a strong legitimating function in organizations. Simultaneously, however, a micro-level investigation of the processes through which innovativeness is constructed unveils the multiplicity of different voices in organizational innovation pursuits (Mumby \& Clair, 1997) and the subtle forms of resistance resulting from the plurality of meanings held by organizational actors.

While innovation management literature has been criticized for emphasizing formal prescriptions of innovation as it should happen (Brown \& Duguid, 1991), studies drawing on the sensemaking and practice approaches have elucidated the pluralism underlying processes of innovation. Work drawing on sensemaking has, for example, focused on the interpretation of market knowledge and knowledge sharing during the development and implementation stages of innovation processes and acknowledged differences between interpretive frames of different occupational groups (Dougherty, 1992; Bechky, 2003). Practice studies have, on the other hand, illuminated the actual processes of innovation (e.g. Brown \& Duguid, 1991; Garud et al, 2011) and identified discrepancies between the formal managerial models and the messy everyday practice through which innovation unfolds (Lempiälä, 2011). These studies have produced valuable understanding of the complexity of innovation and pointed out that the deployment of organizational structures that undermine this complexity may have counterproductive consequences.

The present study seeks to extend these perspectives by focusing particularly on the discursive construction of innovativeness and its controversial nature in everyday organizational talk. One important focus is on the subjectivities that are constructed in the managerial discourse and the ways in which employees 
relate to these in their accounts. Although earlier analyses on the innovation discourse have brought up interesting features of the dominant notions of innovation at the societal level (Sveiby et al, 2012), illumination of the subjectification tendencies and the related power effects, as well as potential identity struggles, have remained outside the scope of these discussions.

\subsection{Research focus and research questions}

In the present study, I investigate organizational efforts to increase innovativeness, including the development of existing idea management tools, setting up new collaborative procedures and structures such as ideation labs, and altering the physical environment of the whole organization to foster an innovative organizational culture. The focus of the analysis is on the managerial justifications for the methods that were used to stimulate innovativeness, with a particular interest in the subject positions imposed on employees through the managerial discourse. From the perspective of employees, my focus is on the meanings ascribed to the innovative efforts and their own positioning within these meanings. The theoretical framework for studying these phenomena draws from the discursive approach to organizational analysis. The focus is particularly on managerial means for controlling innovative behavior through subjectification (Fleming \& Spicer, 2014), and employee resistance from the perspective of micro politics of interaction, i.e. individual meaning making and identity production (Thomas \& Davies, 2005).

Innovativeness is in this study viewed as a discursively constructed phenomenon in the organizational context. A discursive approach to organizational analysis means that organizations are viewed as socially constructed by participants (Berger and Luckmann, 1966) through networks of conversations (Ford, 1999). Conversations draw on and contribute to the prevailing discursive practices in an ongoing process. Following this approach, language is viewed as constituting social reality (Berger \& Luckmann, 1966; Gergen, 1985; Phillips \& Hardy, 2002a). Moreover, language use is outcome oriented, which means that language is used to achieve particular ends, for example to do identity work (Potter \& Wetherell, 1987). Language provides people with particular categories of social reality, such as innovativeness, while individuals simultaneously also participate in maintaining and contesting meanings attributed to these categories (Segercrantz, 2012). Discourse analysis provides a way to unpack this production of social reality (Phillips \& Hardy, 2002b) and thereby explore processes of organizing and the struggles within organizational life (Mumby \& Clair, 1997; Putnam et al, 2005).

Earlier research on innovativeness has sought to identify individual level factors (e.g. Jaussi et al, 2007; McAdam \& McLelland, 2002), as well as cultural (e.g. Amabile et al, 1996; Morrison \& Phelps, 1999) and structural factors (e.g. Dahl et al, 2011; Fairbank \& Williams, 2001; van Dijk \& van den Ende, 2002) that stimulate innovative behavior among employees, and investigating correlations between various individual level and organizational factors and their influence on innovative activity (e.g. Oldham \& Cummings, 1996; Scott \& Bruce, 1994). This body of research primarily builds on a realist ontology, viewing innovativeness as an objective and measurable attribute. 
By taking a discursive approach, the present study brings a novel perspective to the existing work on innovativeness. Instead of viewing innovativeness from a realist perspective and as phenomenon that can be objectively managed, innovativeness is viewed as a hegemonic discourse, which legitimizes particular values, aspirations and modus operandi in contemporary organizations. Following this, the discourse legitimizes particular managerial strategies that seek to control the behavior of employees towards organizationally meaningful creative endeavors.

The empirical data of this study is comprised of semi-structured interviews, audio recorded meeting discussions as well as observation in company premises conducted in six large organizations. Through this empirical material, I explore how the innovativeness discourse is reproduced in managerial talk and how employees respond to the managerial constructions. By doing this, I elucidate the struggles over meaning concerning innovativeness and particularly the negotiation over subjectivity concerning innovative activity. More specifically, I have approached this through the following overarching research question:

- How, and with what consequences, do managers and employees discursively construct conceptions of innovativeness?

I have addressed the overarching research question through the following sub questions:

- What kinds of innovative subjectivities are constructed in the managerial discourse of innovativeness?

- What kinds of meanings do employees ascribe to innovativeness and how do they relate to the managerially imposed innovative subjectivities?

- What kind of pragmatic consequences do the subjectification efforts have on the innovative pursuits initiated by the managers?

\subsection{The structure of the thesis}

This thesis introduction consists of six chapters: Introduction, Theoretical framework, Research approach, Article summaries and results, Discussion and Conclusions. The original articles are appendices of this Thesis introduction.

The Theoretical framework consists of five sections. First, I will elaborate on the discursive approach to organizational analysis. Following this, I will discuss the key features of the innovation literature and how innovation has been addressed from the discursive perspective. The third section discusses subjectification as a form of organizational control, and in the fourth section, I review literature on employee responses to subjectification, focusing particularly on different approaches to resistance. The fifth section provides a short summary of the theoretical framework.

In the third chapter, Research approach, I discuss the methodological foundations of the study as well as the empirical context. In addition, the chapter explicates the methods of data generation and the analytical approaches employed 
in the study. Finally, the chapter provides reflections on the processes of data generation and analysis.

In the fourth chapter, Article summaries and results, I provide short summaries of the four articles that form the core of this thesis. Following the summaries, I discuss how the results of each article contribute to the research questions defined in the beginning of this thesis through integrating the results from the four articles under each research question.

In the fifth chapter, Discussion, I discuss the findings and contributions of this study, reflecting on prior literature. In addition, I discuss the limitations of the study and propose future research directions. The sixth chapter concludes the thesis with a brief summary of the findings and implications of the study. 


\section{Theoretical framework}

The purpose of this chapter is to present the theoretical framework of the study. First, I will elaborate on the discursive approach to organizational analysis. Following this, I will briefly discuss key features of the innovation literature. The third section discusses subjectification as a form of organizational control, and in the fourth section, I review literature on employee responses to subjectification, focusing particularly on different approaches to resistance. The fifth section provides a short summary of the theoretical framework.

\subsection{Discursive approach to organizational analysis}

The present study takes a constructionist approach to innovativeness by viewing it as a culturally produced discourse. Following Foucault (1972:49), discourses are bodies of knowledge that "systematically form the object of which they speak". They are structured collections of texts, and related practices of textual production, transmission and consumption that are located in a historical and social context (Fairclough, 2005). Text refers to written and verbal transcriptions but it also includes any kind of symbolic expression, including cultural artefacts, visual representations, buildings, clothes, etc. (e.g. Hardy \& Phillips, 2004). Discourse is thus not only composed of linguistic components, but is also embedded in material practices. In the context of innovation, this means that not only the talk and text, but also the various structures and practices through which innovation is supported and exercised, represent and contribute to the production of the discourse.

Discourse is both socially constituted and socially constitutive through the way in which it produces objects of knowledge, social identities and relationships between people (Hardy \& Phillips, 2004; Hardy \& Thomas, 2014). Thus, following Potter and Wetherell (1987), discourse does not merely describe things, but it does things. This means that discourses are interrelated to the institutional and social practices that define people's lives and what can be said and done in particular social contexts (Burr, 2015). Discourse thus governs the way that a topic can be meaningfully talked about and reasoned about (Meriläinen et al, 2004). While discourse defines an acceptable way to talk and act, it simultaneously marginalizes alternative ways of talking and conducting 
oneself (Burr, 2015; Grant et al, 2004). Each discourse brings different aspects into focus, raises different issues for consideration and thus constructs the world in a different way, and there may be a number of different discourses, which construct an object differently (Burr, 2015). However, some constructions will have a greater tendency to be seen as common sense or more truthful than others, and thereby achieve a dominant status-although this varies between cultures and locations in history (Burr, 2015; Phillips \& Hardy, 2002b).

Discourses make us see the world in a particular way, and therefore they produce our knowledge of the world (Burr, 2015). What is currently taken as knowledge defines what is possible for one person to do to another under which rights and obligations and, therefore, following Foucault (1977), knowledge is linked to power. Discourses control a society and its members efficiently and without force, through what Foucault calls "disciplinary power" (Foucault, 1977). This means that individuals adopt practices that are not necessarily in their own interest but that are in the interests of powerful groups in society (Foucault, 1977). The practices legitimized within these discourses become natural and obvious, and individuals discipline themselves to act in accordance with the objectives of the powerful groups (Foucault, 1977, 1978). Thus, the social control of the dominant discourses operates unnoticed. The purpose of a discursive approach to organizational analysis is to make visible the power relations maintained in various managerial discourses, and challenge the takenfor-granted understandings that the discourses reproduce (e.g. Phillips \& Hardy, 2002b). In the context of organizational analysis, scholars have, for example, illuminated the disciplinary power of the strategy discourse (Knights \& Morgan, 1991), the HRM discourse (Townley, 1993) and the discourse of entrepreneurship (Ogbor, 2000).

Analyses focusing on culturally hegemonic discourses have been criticized for producing a socially deterministic view of their operation in society. Thus, scholars building on Foucault's work have extended the focus from the analysis of macro-level culturally dominant discourses to the relationship between the macro discourse and the locally produced text and talk that take place in a particular institutional context. These studies direct focus towards how the culturally dominant discourses are reproduced in everyday interaction (Heracleous, 2002). In Fairclough's terms, this approach focuses on interdiscursivity, which refers to the multiplicity of ways in which the dominant forms of knowledge may be reproduced (Fairclough, 1992). For example, the "collective rationality" (Fleming \& Spicer, 2006), which dominates the field of innovation management and innovativeness, is drawn upon in managerial talk in particular organizational contexts, which again goes through another process of resignification and reappropriation and creation of new meanings via employee discourse (Laine et al, 2016). Through interdiscursivity, individuals are able to exercise power by modifying the discourses or mobilizing alternative forms of discourses that they are willing to identify with-thus, strategies of resistance involve power themselves (Hardy \& Thomas, 2014), whereby all actors are situated in "webs of power" produced by the numerous discourses they draw upon (Ezzamel \& Willmott, 2008). 
Vaara (2010) has illuminated interdiscursivity in the context of organizational analysis, particularly from the perspective of the strategy discourse; however, the framework can be applied to the analysis of any other organizational discourse, including innovativeness. By drawing on the tradition of critical discourse analysis and the conception of discourse as a multilevel phenomenon, Vaara distinguishes three different levels of strategy discourse, including macro level, meso level and micro level (Figure 2). The macro-level discourse refers to the broad body of knowledge that contains the key ideas, concepts, practices, methods, etc. around a particular construct, such as strategy, in contemporary society. This body of knowledge is reproduced in the academic, professional, and popular literature and media. Analysis of discourse at this level identifies the "common wisdom" concerning the construct (Vaara, 2010). This level of analysis has also been referred to as the order of discourse (Fairclough, 1992) and the "big D" discourse (Alvesson \& Kärreman, 2000a).

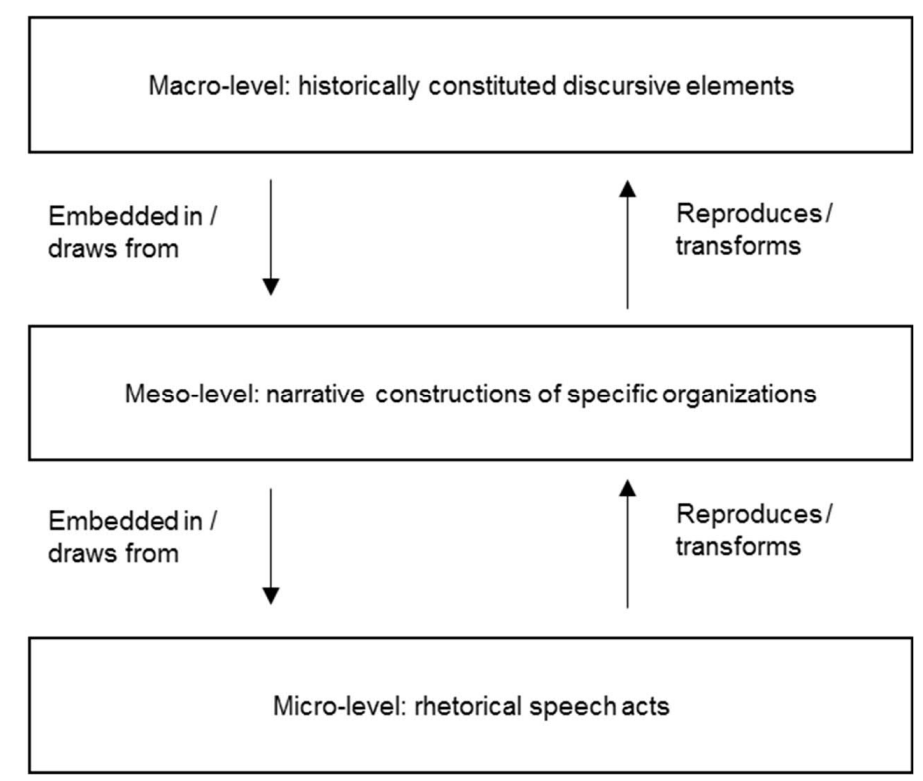

Figure 2. The multifaceted nature of organizational discourse, adapted from Vaara (2010)

Ideologies reproduced in the macro level discourse have significant power effects over organizations as they legitimate and normalize power relations and "the most appropriate" practices and modus operandi within organizational fields (Fleming \& Spicer, 2006). The macro-level discourse is reproduced in organizational narratives concerning the particular organizational domain, for example strategy (Vaara, 2010). While these organizational narratives reproduce the general contemporary discourses, they have their special characteristics, as they are adapted to a particular organizational context. Some of the organization-specific narratives may also acquire an official status in the organizational discourse, but there may indeed be other narratives and some of them may be 
loosely coupled with or even question the official narrative. The multiplicity and diversity of narratives gives voice to different actors. The various strategy narratives, for example, may complement each other in organizational strategizing and provide alternatives for the official strategy (Vaara, 2010). This is illuminated, for example, in the study by Laine \& Vaara (2007), which shows how organizational actors mobilized their own strategy narratives to legitimize their role in strategizing, which ran counter to the managerial plans.

Finally, the micro-level discourse concerns the everyday social interaction in organizations in which the macro- and meso-level discourses are consumed and reproduced (Vaara, 2010). It is through the actual conversations between people that organizations are "talked into being" (Boden, 1994: 215). These discussions include all kinds of interactions in both formal and informal arenas and the focus is thus on the discursive devices that individuals draw upon to achieve particular ends. The micro-level analysis draws attention to the ways in which individuals are capable of mobilizing and drawing on discourses in a way that furthers their own interests and further change by adapting the macro-level discourse to the local settings (Hardy et al, 2000).

\subsection{The discourse of innovation}

The macro-level innovation discourse consistently produces innovativeness as a desirable and essential attribute of nations and organizations (Fougeré \& Harding, 2012). The academic literature contributes to this by seeking to identify the best practices and optimal conditions that result in organizational innovativeness. Following Anderson et al (2014), the dominant research approaches to innovation can be classified based on the level of analysis to studies that focus on the influence of 1) individual-level factors on creativity, for example thinking styles and identity; 2) team level factors such as structure, composition, and leadership style on work group innovativeness; 3) organizational level factors including for example structure and strategy, culture and climate, and corporate entrepreneurship in facilitating innovation, and 4) multilevel analysis, including the relationship between individual, team level and organizational factors. The majority of these studies are occupied with identifying and evaluating the antecedents of innovative behavior and finding the optimal solution for an efficient innovation process, invoking an instrumental and unambiguous view of organizing for innovation (Anderson, 2014, Segercrantz, 2012).

The discourse of innovation has rarely been subject to critical attention; however, a few scholars have raised their concern over the biased nature of the macro-level innovation discourse. For example, Kimberly (1981) introduced the term "pro innovation bias", which pointed to the concern over the presumption that innovation is a desirable characteristic and that positive outcomes will invariably arise from all forms of innovation. The same issue was brought up decades later by Sveiby et al (2012), who raised the concern over the separation of research on innovation and the consequences of innovation. Anderson et al (2014) suggested that the contemporary innovation discourse is based on sim- 
plified assumptions concerning the factors underlying organizational innovativeness. The assumption underlying the discourse appears to be that if a factor or variable correlates with innovativeness, then a higher level, or increase of that variable, will lead to higher levels of sustainable innovation. These assumptions do not, for example, take into consideration the context specific nature of innovation, nor that innovation does not necessarily benefit all parties affected, and excessive innovation may even be counter-productive to other aspects of individual, team, or organizational performance (Anderson \& King, 1993).

Unlike the strategy research within which discursive approaches have been extensively employed (see e.g. Balogun et al, 2014), the domain of innovation still lacks the nuanced understanding of the plurality of ways in which the discourse is reproduced in organizations. In the context of innovation, meso-level and micro-level organizational talk has rarely been addressed from a linguistic perspective, though some exceptions exist. Deuten and Rip (2000) and Bartel and Garud (2009) have discussed how narratives of innovation operate in organizations. Bartel \& Garud (2009) discuss narratives as cultural mechanisms that facilitate the coordination challenges related to the different stages of the innovation process (genesis of novel ideas, commercialization, and sustaining innovation over time). Deuten \& Rip (2000), on the other hand, illustrate how managers were able to generate commitments and acquire resources for the purpose of the development process through mobilizing a narrative of a successful product. The paper interestingly illustrates how the managers positioned themselves in the narratives-thus creating particular roles and commitments (subjectivities)-and how these roles became parts of other peoples' narratives, which reinforced the constructed roles. The above studies saw innovation narratives as the production of shared organizational sensemaking which further innovation processes by enabling sharing of knowledge, but do not address the possible plurality of narratives concerning innovation and how they are reproduced in the micro-level conversations.

The diversity of perspectives related to innovation has been addressed by practice scholars who have criticized the tendency of innovation management research to provide abstract representations of the innovation process "as it should happen," and the underlying idea that under optimal conditions innovation is a clear and predictable process (Brown \& Duguid, 1991; Lempiälä, 2011). Studies drawing on the practice approach have illuminated the complex and emergent processes through which idea development takes place at the grass roots level (e.g. Brown \& Duguid, 1991; Garud et al, 2011; Lempiälä, 2011). For example, Lempiälä (2011) identified discrepancies between the formal innovation structures that management relies on and the messy everyday reality of idea development, particularly its collaborative nature. The study shows how the simplified managerial ideals of the innovation process were in conflict with and even hindered the emergent and iterative praxis of innovation. Here, the managerial ideals of innovation are built on a differing understanding of idea development than that of the idea developers themselves.

Moreover, work by Bechky (2003), Dougherty (1992) and Dougherty et al (2000) has discussed the discrepancies between sensemaking among different 
occupational groups, and thus addressed the role of language in the innovation process. Drawing on an ethnographic approach, Bechky (2003), for example, studied how the lack of contextual understanding created confusion between engineers, assemblers and technicians when discussing problems that had arisen during the development process. Dougherty (1992), on the other hand, studied the ways in which organizational members make sense of market and technology knowledge for innovation, and how innovative and non-innovative organizations differ in these terms. Dougherty et al (2000) identified differences in the sensemaking of various occupational groups involved in the product development process and discussed how the inability to share knowledge between these groups-due to the divergent ways to make sense of technology and market knowledge-had negative influence on product development processes by creating knowledge gaps between the groups. In these studies, lack of mutual contextual understanding and shared language created hindrances to the innovation processes.

The above-discussed approaches that challenge the mainstream innovation literature bring up interesting and important features of the dominant notions of innovation and acknowledge the pluralism inherent in innovation practice. While these studies implicate that innovation and innovativeness bear differing meanings in the contemporary organizations, they have not addressed the discursive constructions of these concepts. Moreover, illumination of the subjectification tendencies as well as potential identity struggles has remained outside the scope of these studies.

\subsection{Subjectification as a form of organizational control}

Discourses entail within them implicit subjectivities, addressing individuals as particular kinds of people (e.g. Knights \& Morgan, 1991). Individuals are the subjects of various discourses and subjectivity is understood in terms of the positions available within discourses (Burr, 2015; Davies \& Harré, 1990). Discourse thus regulates not only what can be said about a particular object, but also from what position an individual can speak. Studies drawing on the Foucauldian interpretation of discourse focus on the way in which broader cultural discourses construct subjectivities that both enable and limit a range of social practices. Following social constructionism, individuals construct their identities out of the discourses culturally available to them, and which they draw upon in communications with other people (Burr, 2015). More specifically, identities are viewed as comprising of the multiplicity of various subject positions individuals take up when engaging in discourse (Reissman, 1993). An identity can be defined as a context-specific "reflexively understood version of one's self" (Alvesson \& Robertson, 2016: 10). Constructions of identity answer questions concerning who one is and how one should act in particular situations. Thus, identity denotes a particular way of feeling, valuing and thinking (Alvesson, 2002). A subjectivity, on the other hand, refers to an implied position within a particular discourse that may be occupied or taken up by a person, providing a basis for their identity and experience (Davies \& Harré, 1990). 
The subjectivities available within discourses bring with them a structure of rights by defining the possibilities and the limitations concerning what an individual may or may not do and claim for oneself within a particular discourse (Burr, 2015). Individuals are constantly addressed by a multitude of different discourses, and identities are derived from both subject positions in broad societal discourses and from positions claimed or resisted within social interactions (Davies \& Harré, 1990). Thus, self-positioning in discourse is an ongoing process in which some positions are taken up temporarily, whereas others become more permanent. Some positions may be experienced as contradictory, and may spur resistance or dis-identification, whereas others may be identified with and adopted either unconsciously or consciously as part of the individual's identity narrative (Segercrantz, 2012). Resulting from this, identity is not a monolithic construct, but instead an ongoing process of identity work through which individuals maintain and repair the constructions that are productive of a sense of coherence and distinctiveness (Alvesson \& Willmott, 2002). Taken together, identity construction is a complex process of interplay between the subject positions provided by the cultural discourse as well as the locally negotiated discourse and the individual identity narratives.

Organizations as discursive regimes are influential in providing actors with resources for identity construction (Tretheway, 1997) and for the legitimization of social practices, which lead people to constitute themselves, their work and their organization in particular ways (Brown et al, 2010). Therefore, organizations are focal sites of subjectification, which can be defined as the process through which particular subject positions are imposed on individuals through discourse (Fleming \& Spicer, 2014). In the context of organizational analysis, subjectification is constructed as a managerial control mechanism, which can be mobilized through various forms of managerial discourse. Following Alvesson \& Deetz (1996), in the contemporary organization, objects of management control are decreasingly labour power and behavior and increasingly the mind power and subjectivities of employees. Subjectification aims to constitute identities in organizations in such a way that employees manage themselves on behalf of organizational interests. Thus, disciplinary power operates by regulating social actors through self-regulation, whereby they "embody the directives of the organization and enforce it upon their identities aspirations and relations with others" (Fleming \& Spicer, 2014: 24). Alvesson and Willmott (2002) use the term identity work to refer to this kind of disciplinary power and have identified diverse ways in which identity is influenced, regulated and changed within work organizations.

Following Alvesson and Willmott (2002), regulatory efforts may take place through 1) defining the individual directly by making explicit reference to characteristics that distinguish a person from others, or by defining the individual indirectly by referring to others for example by pointing out deficiencies of others, and thereby highlighting desired characteristics; 2) referring to appropriate work orientations by providing a specific vocabulary of motives, e.g. by stressing intrinsic motivators instead of instrumental motivators, explicating morals and values through narratives, or accentuating particular knowledge and skills as 
important measures of competence; 3) creating social categories between "us" and "them" to which the individual is ascribed, by developing hierarchical locations through status distinctions between different communities or organizational functions within the organization, or by constructing the entire organization as elite compared to others; and 4) establishing the natural way of doing things in particular contexts and defining the rules of good corporate citizenship, or defining the wider organizational context and the characteristics that are required in order to survive in those conditions. It is noteworthy that identity regulation may be pursued purposefully, or it may be a by-product of other activities and arrangements typically not seen by regulators or the targets of their efforts as directed at self-definition (Alvesson \& Willmott, 2002). For example, the organizational discourse may reproduce a particular kind of ideal personhood to be aspired to by employees, without it necessarily being a managerially imposed hegemony (Thornborrow \& Brown, 2009).

Processes of identity regulation have been discussed along two fronts: first, as an ongoing process of production of the preferred organizational identity, and second, in the context of organizational change processes in which management has sought to bring about change in employee identities by mobilizing new managerial discourses. Studies viewing the ongoing process of identity regulation have demonstrated how the various forms of identity regulation become manifest and are achieved in organizations through the continuous reproduction of the desired identity in the organizational discourse, which disciplines employees' identity work (e.g. Bergström \& Knights, 2006; Gotsi et al, 2010; Brown et al, 2010; Thornborrow \& Brown, 2009). Adoption and aspiration of the preferred identity is driven by the need to fit into the social networks and relations within the organization (Brown et al, 2010). The production of the preferred individual has been explored as an ongoing organizational process, in which employees engage in reproducing the preferred identity in organizational discourse. This can be either something that is imposed on employees by management or a form of identity that is constructed as the ideal within the work community, and the need to follow the social norms of a particular organizational context drives individuals to pursue such identity.

The study by Thornborrow and Brown (2009), for example, illustrates how the organizationally based discursive resources disciplined the preferred selfconceptions of men in a military unit. The authors show how paratroopers were subject to and constituted by the discursive practices of the regiment. The study illustrates how the regiment produced and reproduced the idealized identities to which they aspired. In a similar vein, Brown \& Coupland's (2005) study on graduate trainees in a consultancy firm illuminates how the need to fit in resulted in compliance of the normative rules of the company, which in this case was achieved through refraining from articulating one's views or asking for help. The normative rules were not explicitly stated, but rather deducted from the management responses, based on which the ideal types of worker had been constructed by the trainees. 
In the context of organizational change, scholars have addressed processes of subjectification of several managerial discourses. Through mobilizing managerial discourses such as teamwork (Knights \& McCabe, 2003), business planning (Oakes et al, 1998), enterprise discourse (Doolin, 2002), Total Quality Management (Knights \& McCabe, 2000) and New Public Management (Thomas \& Davies, 2005; Halford \& Leonard, 2005), new kinds of preferred subjectivities have been introduced in organizations. The study by Knights and McCabe (2003) illustrated how managers reconstituted employee subjectivity in a call center by mobilizing a discourse of teamwork. The discursive practice of team working emphasized the autonomy inherent in the new regime and although it conflicted with some aspects of employee identity, it managed to generate a new kind of organizational atmosphere in which people adopted greater responsibility and autonomy.

Drawing on Bourdieu's concept of pedagogy and institutional theory, the study by Oakes et al, (1998) illustrated how the introduction of business planning in the context of provincial museums and cultural heritage sites changed the rules of legitimacy of the organizations and the subject positions of organizational actors. Through the introduction of business planning, what was valued in the field shifted from representing a historian's view of authentic culture and artifacts to a concern with what will generate revenue and visitors. Moreover, the study illuminates the subtlety of the "symbolic violence" exercised upon individuals by the pedagogy of business planning. This means that through a process of seemingly very technical changes, the desirable subjectivities changed from curator, researcher, interpreter or educator to include an entrepreneurial mindset that would come up with business opportunities. Thus, the discourse of business planning replaced the meanings that had been defined by the producers within the field, with another set of meanings that was defined by the discourse of business planning in reference to the external market (Oakes et al, 1998).

In the realm of innovativeness and creativity, the regulation of employee identities has been acknowledged as particularly challenging, albeit discussions on identity in this context are rare. The ethos of creative freedom is viewed as conflicting with the constraints imposed on the activity by the business requirements creating identity tensions (Andriopoulos \& Lewis, 2009; Gotsi et al, 2010). The management or regulation of an innovative identity has been discussed as requiring balancing between encouraging and facilitating creative behavior and adopting a business mindset, which ensures that the creative efforts are targeted towards organizationally meaningful directions. Gotsi et al (2010) identified particular strategies employed by managers to regulate the identity of creative workers to direct the creative efforts towards organizational goals, and thus manage the "innovation paradox". This was achieved through separating the artist and consultant roles in time and space (differentiation), or discursively encouraging an identity that embraces both roles simultaneously (integration), thus fostering individuals' conceptions of self as "practical artist". Here, the management sought to promote practical artist as the desired identity among creative workers. The issue was not about compelling people to engage 
in creative work, but instead about becoming creative in a sense that is organizationally meaningful, and thus directing them towards considering organizational benefits. In a similar vein, in their multilevel study on organizational ambidexterity, Andriopoulos and Lewis (2009) discussed how managers sought to cultivate "paradoxical work identities" among creative workers through socialization, as well as temporal and spatial differentiation between ideation and experimentation versus administrative elements of work. These studies, however, focused on managerial strategies, leaving employee responses to identity regulation unaddressed.

Overall, the above studies illuminate how the various systems of management control seek to "colonize" the identities of workers so that they adopt the kind of subjectivity that is compatible with the productive demands of the contemporary organization (Fleming \& Spicer, 2003). However, managerial hegemonies can never adequately represent all the interests in an organization (Spicer \& Böhm, 2007) and therefore, all dominant managerial discourses remain incomplete. Following this, "resistance always lurks within any hegemonic regime” (Spicer \& Böhm, 2007: 1671). Next, I will review earlier research on employee responses to managerial attempts of colonizing their identities.

\subsection{Resisting identity regulation}

A long tradition of research has explored the various ways employees resist managerial control. Employee resistance has been classified into formal and routine forms-formal resistance refers to organized protests, strikes and absenteeism, whereas routine resistance refers to the quotidian forms of resistance (Prasad \& Prasad, 2000). Formal resistance is rarely witnessed in the contemporary organization, as under "an ideological regime of commitment and unitary interests" it is unprecedented that employees would overtly resist the managerial regimes (Fleming \& Sewell, 2002: 860). Moreover, overt resistance is readily labeled as activity of troublemakers and outsiders, and therefore against social norms (Fleming \& Sewell, 2002). Thus, in the contemporary organization, employee opposition manifests in more subtle forms (Fleming \& Sewell, 2002; Fleming \& Spicer, 2003), and organizational scholarship has sought to identify the various ways in which employees respond to cultural control targeting their identities.

Traditional research on resistance has been criticized for framing resistance as a simplistic worker management dialectic and failing to appreciate the ambiguity and complexity surrounding resistance (Piderit, 2000; Thomas \& Davies, 2005; Thomas \& Hardy, 2011). Moreover, it has been criticized as being locked within a negative paradigm and seen either as overt or covert employee responses to the oppressive forms of managerial control, ignoring the more nuanced manifestations of power-resistance relations in everyday organizational interaction (Piderit, 2000; Thomas \& Hardy, 2011). Lately, scholars have sought to move away from the thinking that resistance would be irrational and dysfunctional, resulting from individual level psychological defects and instead viewing 
it from the perspective of attitudes as rhetorical stances (Symon, 2005; Näsänen, 2018). Discursive studies drawing on Foucauldian notions of power have sought to understand resistance at the level of meanings and identities, viewing resistance as a continuous process of "adaptation, subversion and reinscription of dominant discourses” (Thomas \& Davies, 2005:687). This process of "micro politics of resistance" takes place as individuals confront and reflect on their own identity performance-recognizing contradictions and tensionsand in so doing, subtly shift meanings and understandings (Thomas \& Davies, 2005). Thus, resistance can be viewed as being stimulated by the contradictions between alternative subject positions. Moreover, responses to subjectification are not simplistic either-or responses, where individuals would explicitly be for or against the managerially imposed subjectivity, but rather they are complex, contradictory and changing through time. Instead of fully resisting the managerially imposed subjectivity, individuals may identify with some aspects of it while resisting others (Humphreys and Brown, 2002; Piderit, 2000), and the forms of identification with the managerial discourse may vary between full identification, partial identification (i.e. schitzo-identification) and total disidentification (Elsbach, 1999).

Empirical research focusing on employee discourse has explored micro politics of resistance in various contexts and has identified different ways in which employees contest managerial subjectifications. Employees have been found to draw upon other notions of self, such as parenthood or gender, to resist managerial subjectification (Thomas \& Davies, 2005; Knights \& McCabe, 2003), while in other studies the managerial discourse has been experienced as conflicting with the professional identity or the ethos of the professional practice (e.g. Doolin, 2002). Moreover, in the context of strategic change, Laine and Vaara (2007) found that the managerial discourse was constructed as restricting individual agency, which spurred the need to create room for maneuver by legitimizing alternative ways of engaging in strategizing through the local negotiation of meanings (Laine \& Vaara, 2007).

The introduction of managerial control schemes in public organizations has inspired a multitude of research concerning identity conflict and struggles over subjectivity. In the context of public services, the professional orientation and the public service ethic is a central source of identification (Thomas \& Davies, 2005). In such contexts, the introduction of financial accountability and the resulting change in the relationship between the service provider and the customer, produces value conflicts. For example, in a study by Doolin (2002) concerning the introduction of clinical leadership strategy in a public hospital, acceptance of management as legitimately controlling healthcare delivery represented a betrayal of clinicians' professional identity. Resistance arose from the positioning of clinicians as subjects within a medical professional discourse, which held different values from that of the leadership discourse. Here, resistance was strongly tied to the specific context, as the clinicians did adopt a leadership discourse when operating in their own private clinics while neglecting it in the context of a public hospital. 
Thomas \& Davies (2005) on the other hand found that employees drew on "self as other", e.g. a mother, female manager or public service professional, to legitimize their dis-identification with the subject positions imposed by the New Public Management (NPM) discourse. Moreover, the study shows, how the looseness of meanings around NPM allowed individuals to appropriate different meanings in reflections of self in conjunction with NPM. The paper illustrates how individuals exploit the contradictions within the NPM discourse and the multiplicity of positions they may draw from when negotiating their identity. Similarly, in their study of police officers Dick and Cassels (2002) observed organizational actors constructing counter discourses to create a mental space to avoid complete subjectification, and thus resistance was a kind of a mental coping strategy when the values proposed by the managerial regime were in conflict with the personal identity narratives (Dick \& Cassels, 2002). "Resistance" is thus covert from the organizational perspective but allows for the legitimization of one's identity within the hegemonic discourse.

While dis-identification or "psychological distancing" (Whittle, 2005) from the managerial hegemony is referred to as resistance, the question has been raised whether such coping strategies in fact count as resistance (Fleming \& Spicer, 2003, 2007; Whittle, 2005). Employees have been found to very strategically employ the managerial discourse and comply "on the surface" to the managerially set subjectivity requirements while being highly cynical and disengaged with it at a personal level. For example, studies by Brown et al, (2010), Brown and Coupland (2005) and Whittle (2005) illustrated how employees adopted the subjectivities proposed by the managerial discourse consciously and for highly instrumental purposes. In the study by Brown and Coupland (2005), remaining silent was a coping strategy which made junior consultants appear compliant on the surface, although they did not agree with the managerial practices. In a similar vein, the study by Whittle (2005) shows how although management consultants did not identify with the discourse of new work they were selling to customers, it did not fundamentally disrupt or disturb the production of the consulting discourse.

Thus, the studies show how individuals reproduced the organizationally dominant rhetoric, although they were not personally convinced by it or committed to it. Therefore, it could be argued that forms of psychological distancing do not in fact constitute resistance, as practices are left unaffected (Fleming \& Spicer, 2003; Whittle, 2005). In cases where employees do not identify with the values and philosophy of the organization, a regime of ideology still seems to work-at least in many cases, as individuals comply to the practices even though they would not necessarily mentally identify themselves with the regime (Fleming \& Spicer, 2003; Whittle, 2005).

Although the management of innovation and thus innovative subjectivity is acknowledged as a tensioned endeavor, resistance or identity struggles have rarely been discussed within this domain. A couple of studies touching upon the subjectification of the innovation discourse, however, do exist. Earlier work has pointed out that the innovation process and the related managerial discourse produces particular subjectivities for consumption by employees, and that these 
may be in conflict with the employees' identities. The study by Segercrantz, for example (2012), illuminated how the formalization of innovation processes resulted in dissociation from the ways of organizing for innovation among ICT experts. The study discusses how the ICT experts' subject positions shifted such that, having been positioned as autonomous craftsmen with control over their own work, their autonomy was reduced, and they were increasingly positioned in terms of productive resources and passive receivers of tasks during downsizing. Thus, the downsizing resulted in fewer opportunities to negotiate agency and implied a shift from identification with the subject positions constructed in the organizational discourse toward dis-identification.

Another study by Lempiälä et al (2018) explored how two different teams in the same organization perceived their possibilities for employee-driven innovation. While in one team the employees interpreted innovation structures as limiting their agency, another division interpreted them as enabling their ability to engage in innovation. Thus, difference in the collective identities between the two teams was reflected in the differing ways in which the organizational structures were interpreted. This study illuminates the locally negotiated nature of meaning concerning the structures through which innovativeness is pursued in organizations and how they can be interpreted as positioning the organizational actor with limited agency.

While not specifically framing these processes as resistance, in the context of innovation the previous studies illuminate how the construction of an "innovative identity" influenced the way in which organizational structures were interpreted and innovativeness was integrated to the identity narrative, resulting in disengagement among employees with respect to organizational efforts to pursue innovation.

\subsection{Summary of the theoretical framework}

Studies drawing on discursive approaches to organizational analysis seek to uncover the processes through which dominant discourses are reproduced and maintained in organizations, and how this contributes to the construction of the social reality of organizations. A multitude of established managerial discourses have been studied from this perspective, unveiling the processes through which particular subjectivities, values, aspirations and modus operandi become legitimized in contemporary organizations. Focus on organization-specific narratives and micro-level organizational talk, in which the dominant discourses are reproduced, elucidates the polyphonic nature of organizational discourse, representing organizational life as a continuous struggle between power, resistance and an individual sense of subjectivity. In a similar vein as other managerial discourses, innovation may be scrutinized as a discourse through which management seeks to control the behavior of employees towards organizationally meaningful creative endeavors and produces particular innovative subjectivities for the consumption of employees.

The managerial discourses in contemporary society seek to influence employee identities to directions that benefit organizational productivity through 
a number of identity regulation strategies. Earlier research has explored how managerial control mechanisms operate in organizations and colonize employee identities to achieve desired forms of organizational culture. These are at least seemingly efficient control mechanisms since in contemporary organizations it is against the social norms to be overtly resistant. Work on micro politics of interaction has, however, found that employees do indeed resist the managerial hegemonies-at least to the degree that they conduct their work at a cynical distance. This means that they do not identify with the managerially imposed subjectivities, although they do comply with the managerial control mechanisms "on the surface". Thus, "resistance" is in many instances primarily a mental coping strategy, which enables the individual to distance oneself from the values of the managerial hegemony.

While the sensemaking studies and practice studies have illuminated the ambiguity of innovation, research in this field continues to be dominated by realist studies that focus on identifying and evaluating the antecedents of innovative behavior and finding the optimal solution for an efficient innovation process. These studies invoke an instrumental and unambiguous view of organizing for innovation, neglecting the processes of social interaction in and through which innovation and innovativeness are constructed in organizations. In addition, although the management of innovative activity has been acknowledged as a tensioned endeavour, and some scholars have discussed identity regulation strategies in the context of innovation, these discussions have been left to the margins. Moreover, these studies have primarily focused on the managerial means of identity regulation, leaving employee meaning making including resistance vis-a-vis the managerial approaches unaddressed. 


\section{Research approach}

In this section, I will elaborate on the epistemological and ontological foundations of the study and discuss two main approaches of social constructionism. The section also presents the research methods and the empirical materials of the study.

\subsection{Methodological foundations}

This study draws on the paradigm of social constructionism, which focuses on uncovering the ways in which individuals and groups participate in the creation of their perceived social reality (Danziger, 1997). Social constructionism builds on a relativist ontology, which infers that there is no universal, objective truth, but rather, each point of view has its own truth (Burr, 2015). It argues that even if an objective reality exists, we do not have access to it, because the second we begin describing it, we start assigning meanings to it which are always socially constructed (Hall, 2001). As to the epistemology, social constructionism views all ways of understanding as bounded to their historical and cultural contexts. Instead of treating knowledge as derived from the nature of the world as it really is, knowledge is understood to be created and sustained by social processes (Burr, 2015). Knowledge is created through talk, in which people construct particular accounts of what the world is like (Burr, 2015). While language use sustains the social reality, it simultaneously transforms it. Some aspects are highlighted while others are left out, in which case the self-evident nature of particular areas of the reality weaken while others intensify. Thus, following Berger and Luckmann, (1967:44) the taken-for-granted is not an atemporal concept, instead, something is taken for granted "until further notice".

Two main approaches underlying the broad spectrum of social constructionist research, namely micro social constructionism and macro social constructionism (Burr, 2015) (or light social constructionism and dark social constructionism (Danziger, 1997)) are identified in the existing literature. Micro social constructionism sees social construction taking place within everyday discourse and interactions between individuals. The approach focuses on the construction of accounts and personal identities within interpersonal interaction, highlighting the multiplicity of constructions produced by people. Macro social constructionism, on the other hand, focuses on the constructive force of the culturally available discourses and the focus of analysis is on the operation of power rela- 
tions in discourse (Burr, 2015). The most influential representative of macro social constructionism is Foucauldian discourse analysis (Heracleous, 2001). Macro social constructionism acknowledges the constructive power of language but sees this as bound up with material or social structures, social relations and institutionalized practices. Thus, while micro social constructionism treats discourse as an emergent and locally constructed phenomenon and focuses on the complex social practices and variations at the level of interaction, macro social constructionism focuses on general patterns and culturally standardized discourses that are associated with particular social settings (Alvesson \& Kärreman, 200ob). Critical discourse analysis (CDA), which builds on the tradition of Foucauldian discourse analysis, seeks to understand how the power relations constructed in macro-level discourses are reproduced in micro-level talk and text. Thus, CDA seeks to relate the processes of interpersonal interaction to the structures of the institutional context.

In the field of management and organization studies, scholars have employed CDA to explore the ways in which dominant managerial discourses are reproduced in everyday lived experience (e.g. Doolin, 2002; Laine \& Vaara, 2007; Samra-Frederics, 2003; Thomas \& Davies, 2005). Through analyzing interview material and recorded meeting talk, these studies have illuminated how the power relations are reproduced and how managerial hegemonies are contested through the construction of localized meanings. In these studies, the institutionalized managerial discourse, including managerial practices, serves as a repertoire for actual conversations, which in turn reproduce and may change the discourse (Czarniawska, 2004).

In the individual articles of the present study, the focus is primarily on the micro-practices of interaction in which the discourse of innovativeness is reproduced, and thus the articles are grounded in the tradition of micro social constructionism. However, following the footsteps of CDA scholars, the thesis as a whole seeks to understand the interplay between the micro and macro levels of the innovation discourse. While the innovation management structures implemented in organizations can be considered as fixed manifestations of the culturally established innovation discourse, the micro-level analysis of interaction unveils the localized meanings related to these structres.

\subsection{The context of the study}

For this thesis, I have conducted in-depth case studies producing rich qualitative data within six organizations. In each of the sub studies, theoretical sampling has been the guiding principle for the choice of case organizations. This means that they were chosen because they were most likely to offer a useful extension to current theory (Eisenhardt \& Graebner, 2007). As the focus of the study was on organizational attempts to enhance innovativeness, investigating large organizations was justifiable, as they usually seek to systematize and construct support structures to enhance employee innovativeness. In such companies, the motivation and understanding based on which they support innovativeness, needs to be made explicit and adopted to the realm of organizational 
discourse. In each of the companies studied, particular measures had been taken to increase employee innovativeness including the development of existing idea management tools, setting up new structures such as ideation labs to stimulate innovativeness, and altering the physical environment of the whole organization to foster an innovative organizational culture. Four of the case organizations represent heavy industries, including iron and steel production, production and development of mining equipment, oil refinement, and production and development of measurement and research devices. Two of the organizations represent the service industry, including the development of financial services for financial institutions and a broadcasting organization.

In Article I, the interviewees were comprised of white-collar R\&D engineers and technology directors in four different organizations. In Article II, the interviewees were oil refinery workers and their managers, while in Articles III and IV, the organization operated in the broadcasting industry. The interviewees of Article III were comprised of journalists, set designers and their managers, whereas the project group observed in Article IV contained people in administration and strategic development. Thus, in terms of the industries and professional backgrounds of the research subjects, the empirical settings of the articles differed significantly. While, for the technological experts in Article I, innovative activity was part of the formal job description, for interviewees in Articles II and III it was an extra-role activity. However, the methods through which managers were trying to enhance innovativeness in Article I were targeted to spur innovations that are radical, and thus can be considered as innovative activity outside of the daily development work. The details of the case organizations and respective interviewees studied in each article are depicted in Table 1. 
Table 1. Case organizations and interviewees

\begin{tabular}{|c|c|c|c|}
\hline Article & Organization & $\begin{array}{l}\text { No. of } \\
\text { employees }\end{array}$ & Interviewees and organizational units \\
\hline \multirow[t]{4}{*}{ Article I } & Process Inc. & 4100 & $\begin{array}{l}10 \text { technology developers and } 5 \text { representa- } \\
\text { tives of upper and middle management from a } \\
\text { specific team dedicated to maintaining continu- } \\
\text { ous development of one of the firm's key tech- } \\
\text { nologies. }\end{array}$ \\
\hline & $\begin{array}{l}\text { Measurement } \\
\text { Inc. }\end{array}$ & 1000 & $\begin{array}{l}6 \text { technology developers and } 3 \text { representatives } \\
\text { of upper and middle management of a concept } \\
\text { development team whose purpose was to de- } \\
\text { velop novel concepts to be internally sold to } \\
\text { business divisions. }\end{array}$ \\
\hline & Finance Inc. & 700 & $\begin{array}{l}7 \text { technology developers and } 3 \text { representatives } \\
\text { of upper and middle management from ICT de- } \\
\text { velopment unit }\end{array}$ \\
\hline & $\begin{array}{l}\text { Construction } \\
\text { Inc. }\end{array}$ & 3900 & $\begin{array}{l}13 \text { technology developers and } 7 \text { representa- } \\
\text { tives of upper and middle management from } \\
\text { the R\&D personnel of different units. }\end{array}$ \\
\hline Article II & Refining Inc. & 2300 & $\begin{array}{l}3 \text { corporate level responsible managers, } 8 \\
\text { evaluators and } 11 \text { suggestion makers from the } \\
\text { same division. }\end{array}$ \\
\hline Article III & Media Inc. & 3500 & $\begin{array}{l}\text { Article III: Seven responsible directors and } \\
\text { managers, } 29 \text { employees from different func- } \\
\text { tions (including } 3 \text { line managers, } 3 \text { administra- } \\
\text { tive staff, } 10 \text { development managers and rep- } \\
\text { resentatives of content production including } 4 \\
\text { journalists, } 4 \text { graphic designers, } 2 \text { set design- } \\
\text { ers and } 3 \text { production coordinators) } \\
\text { Article IV: Project group with } 11 \text { members from } \\
\text { different administrative functions including HR, } \\
\text { IT, strategic development, communications, Fi- } \\
\text { nance, occupational health, occupational } \\
\text { safety and facility services. }\end{array}$ \\
\hline
\end{tabular}




\subsection{Data generation and methods of analysis}

In the following, I will describe the data generation methods and the analytical approaches employed in each study. The data of this study is comprised of semistructured interviews, audio recorded meeting discussions, observations in company premises and document analysis. The analytical approaches of the four articles include qualitative content analysis from the sociological perspective (Prichard, 2004), and three linguistic methods including narrative analysis, rhetoric social psychology and discourse analysis focusing on spoken interaction (Potter \& Wetherell, 1987). Table 2 summarizes the details of the data and the analysis methods employed in each study.

\subsubsection{Data generation methods}

Semi-structured interview was the method of data generation in Articles I, II and III. The interview process can be described as a process of co-production in which the empirical research material is produced in collaboration with the researcher and the interviewee (Meriläinen et al, 2004). The interviews were semi-structured, as my co-author and I brought broad topics for discussion and allowed the interviewees to develop ideas and speak freely about the topics and bring up issues they themselves found particularly relevant. However, we directed the conversation as necessary to ensure that the specific change or innovation process under study would be covered in the conversation. The interviews were 'in-depth' in nature, as we encouraged the interviewees to provide a nuanced and detailed description of their experiences of the innovation and change processes in question. While we allowed the interviewees to describe the issues they found particularly important, the same broad questions were covered in each interview. All interviews were audio recorded and transcribed verbatim.

Non-participant observation was the primary method for data generation in Article IV. Non-participant observation refers to the kind of observation in which the researcher does not take part in the events he/she is observing, and thus has a passive role (Gold, 1958). Therefore, the data is naturally occurring, as the events would likely take place regardless of the researcher's presence. In Article, IV my co-author and I attended program group meetings and recorded the meeting discussions. We were present at the meetings, but we did not produce spoken research material. The program group discussed our presence only in the first meeting and if a new member would join the meetings. While this data construction method is called observation, in practice, we were participating in the meetings in order to record the discussion, and the primary data of the article is comprised of the transcribed meeting discussion. We did make field notes of the meeting situation, but we did not use these in the analysis process, apart from the information concerning who were present in the meetings. The recorded meeting discussions were transcribed verbatim.

We complemented the data in Article I with non-participant observation. The observation data comprised of field notes collected when observing the research participants in their work settings. Observation was carried out in order to gain in depth understanding of the organizational context. Thus, it deepened the insights gained from the primary data, rather than brought up novel discoveries or contradictions related to our findings from the interview material. In Article 
I, we also used company documents for deepening understanding of the organizational context and clarifying our understanding of, for example, the formal organizational processes. The documents primarily included depictions of the innovation processes and innovation programs used in the organizations. Additionally, we examined documents related to organizational structures.

\subsubsection{Analytical approaches}

Various analytical approaches have been employed in the study, and in the following, I will discuss each of them briefly. The original articles contain more detailed discussions concerning the methods and analysis processes. The different analysis methods and data in each study are depicted in Table 2. The analysis processes followed an inductive approach, which means that instead of following set analytical frameworks, we chose the frameworks once the interesting recurring patterns were identified from the data. In practice, this means that we read the interviews through several times, during which we identified the different ways of constructing the innovation or change process at hand. The analytical framework was developed moving back and forth between data analysis and literature. This means that as a whole, the process of matching the data with theory was highly iterative.

In Article I, the empirical material comprises of semi-structured interviews, non-participant observation data in the form of field notes, and company documents. The method of analysis was qualitative content analysis. A distinction can be made between content analysis in the sociological tradition, which treats texts as a "window to human experience," and the linguistic tradition, which treats text as an object of analysis in itself (Prichard et al, 2004: 226). Following this, the method employed in the first paper draws from the sociological tradition, as the object of the analysis has been to find out how people experience and make sense of managerial methods to increase innovativeness, as well as why managers use particular methods. While the research approach employed in Article I treats text differently compared to the linguistic approaches employed in the three other Articles, the method of analysis has not been markedly different, as the objective has been to identify recurring patterns in the way individuals make sense of the innovation practice.

The three other methods represent the linguistic tradition, in which the focus is not on finding out what people think, but to understand how people use language to achieve particular ends. Language is viewed as action, and the interest lies in understanding how speakers manage to build accounts that have particular effects in interaction, as well as constructing and legitimating particular identities for themselves (Potter \& Wetherell, 1987). Thus, while it is not considered to reflect some inner life of the research subjects, language is seen as a tool that is used for specific purposes. The methods of analysis employed in the articles-discursive psychology, rhetoric analysis and narrative analysis-differ slightly from each other with respect to the focus of the analysis. The concern of all these analytical approaches is, however, to study how people use language in 
their everyday interactions and identify discursive patterns, which refer to repeatedly and regularly occurring ways to speak about a particular topic. Next, I will briefly discuss the main principles of each approach.

Article II employs the method of narrative analysis, which considers narrative as the form of structuring individual experience (Sarbin, 1986). Narratives are regarded as tools through which individuals provide an account of events from their own perspective, but also construct their own and others' positions in the process (Buchanan \& Dawson, 2007). Narrative analysis thus focuses on the rich use of discourse embedded in context (Pentland, 1999), particularly emphasizing how people construct and organize their experiences (Bruner, 1990). Article II focuses particularly on the positioning of individuals within change narratives constructed in different employee groups. The approach differs from discursive psychology and rhetorical social psychology as it does not focus on specific discursive devices, but instead on plots and explanations of causal events and the positions of different actors within these.

Article III draws on the traditions of rhetorical social psychology (Billig, 1996), which is focused on the rhetorical strategies individuals use in order to present arguments and counter arguments towards a topic. The approach considers arguments and counter-arguments to be the key part of the social nature of human thinking (Billig, 1996). The approach highlights both variability and ambiguity in the language used, including the matter that an individual takes a stance either in order to support or contest a particular view. This was a useful choice of method for studying how different members of the organization supported and contested the ongoing change.

Article IV follows the principles of discourse analysis, which focuses on spoken interaction (Edwards \& Potter, 1992), and where the focus of the analysis is on the patterns of how people speak about a given topic repeatedly and regularly. More specifically, the approach allowed us to study how accounts of people's tasks and responsibilities were manufactured in naturally occurring meeting discussions, and what they achieved with these constructions (Potter and Wetherell, 1987). The purpose of the study was to understand how members of a program management group negotiated the scope of its activities in organizational change, and instead of restricting our analysis to stances of for or against the change, this approach allowed us to identify a multitude of discursive devices the group employed to construct its position vis-a-vis the change program. 
Table 2. Methods of analysis

\begin{tabular}{|c|c|c|c|c|}
\hline $\begin{array}{l}\text { Article } \\
\text { No. }\end{array}$ & Research question & Focus of analysis & $\begin{array}{l}\text { Data generation } \\
\text { methods }\end{array}$ & Analysis method \\
\hline I & $\begin{array}{l}\text { Why do managerial } \\
\text { efforts to support } \\
\text { creativity lead to ad- } \\
\text { verse motivational } \\
\text { effects and what are } \\
\text { the constituents of } \\
\text { innovators' creative } \\
\text { freedom? }\end{array}$ & $\begin{array}{l}\text { Innovators' accounts } \\
\text { of their motivational } \\
\text { drivers, managers' } \\
\text { justifications of the } \\
\text { approaches used to } \\
\text { increase innovative- } \\
\text { ness }\end{array}$ & $\begin{array}{l}\text { Semi-structured } \\
\text { interviews (54), } \\
\text { observation } \\
\text { (34h), document } \\
\text { analysis }\end{array}$ & $\begin{array}{l}\text { Sociological } \\
\text { tradition, } \\
\text { content analysis }\end{array}$ \\
\hline II & $\begin{array}{l}\text { How is the change } \\
\text { in the suggestion } \\
\text { program con- } \\
\text { structed by different } \\
\text { employee groups? }\end{array}$ & $\begin{array}{l}\text { Fairness perceptions } \\
\text { constructed in the } \\
\text { change narratives of } \\
\text { responsible manag- } \\
\text { ers, suggestion mak- } \\
\text { ers and suggestion } \\
\text { evaluators }\end{array}$ & $\begin{array}{l}\text { Semi-structured } \\
\text { interviews (22) }\end{array}$ & $\begin{array}{l}\text { Linguistic } \\
\text { approach, narra- } \\
\text { tive psychology } \\
\text { (Sarbin, 1986) }\end{array}$ \\
\hline III & $\begin{array}{l}\text { How is the change } \\
\text { from traditional of- } \\
\text { fice to multispace } \\
\text { office rhetorically } \\
\text { constructed by man- } \\
\text { agers and employ- } \\
\text { ees? }\end{array}$ & $\begin{array}{l}\text { The rhetorical strate- } \\
\text { gies employees use } \\
\text { to support and contest } \\
\text { change }\end{array}$ & $\begin{array}{l}\text { Semi-structured } \\
\text { interviews (36) }\end{array}$ & $\begin{array}{l}\text { Linguistic } \\
\text { approach, Rhet- } \\
\text { oric social psy- } \\
\text { chology (Billig, } \\
\text { 1993) }\end{array}$ \\
\hline IV & $\begin{array}{l}\text { How do members of } \\
\text { a program manage- } \\
\text { ment group negoti- } \\
\text { ate the scope of its } \\
\text { activities in organi- } \\
\text { zational change? }\end{array}$ & $\begin{array}{l}\text { The discursive pat- } \\
\text { terns in the program } \\
\text { management groups' } \\
\text { meeting discussions } \\
\text { and how they define } \\
\text { their position }\end{array}$ & $\begin{array}{l}\text { Audio-recorded } \\
\text { meeting discus- } \\
\text { sion (15h) }\end{array}$ & $\begin{array}{l}\text { Linguistic } \\
\text { approach, } \\
\text { Discourse analy- } \\
\text { sis (Potter \& } \\
\text { Wetherell, 1987) }\end{array}$ \\
\hline
\end{tabular}

\subsubsection{Researcher's role in the research process}

In qualitative research, the researcher is part of the social world, which is studied. Therefore, researcher reflexivity is of paramount importance when discussing the ways in which qualitative research may be assessed (Welch \& Piekkari, 2017). Reflexivity refers to the researcher acknowledging her/his role in producing the data, and the underlying premises, values and intentions guiding the analysis process. In the present study, two types of research material were used: naturally occurring meeting talk, which was acquired through non-participant observation and interview material. Moreover, different methods of analysis were employed in each study. In the following, I will briefly reflect on the processes of data generation and analysis, elaborating on the ways in which we as researchers have influenced the unfolding of the research process. 
In terms of the observation in Article, IV my research colleague and I alternately participated in the meetings by sitting at the meeting table or on a couch behind the table. We reflected on the influence of our presence by writing down situations where the participants had paid attention to us and by considering this in the analysis. During the observed meetings, the members of the project group did not address us researchers apart from a few occasions. A few times, if group members for example joked during the discussions, one member of the group explained the jokes or the context for us. This took place less than once per meeting and dimished with the passage of time. We did not speak during the meetings apart from greeting in the beginning and in the end, unless something was brought up concerning our research institutions - however, this was also very rare. As we were part of the group from the very beginning of its initiation, our presence seemed to be very natural for the participants and did not interfere meeting discussion.

Interview material is considered as non-naturally occurring and as co-produced by the researcher and the interviewee. However, an interview is an efficient way to bring about talk concerning a selected topic, and it allows interviewees to speak about the topics from their own perspectives (Nikander, 2012). In Articles I, II and III we sought to interview employees from different levels of the organization to get a multidimensional perspective to the process in question. To ensure this, we chose the interviewees based on their organizational position. In the interview situation, we sought to create a confidential setting where interviewees could explain their personal experience of a particular process. We avoided questions that would assume some kind of an attitude towards the topic at hand, but instead sought to maintain the questions neutral. Moreover, we stressed the confidentiality of the handling of the interview material.

As interviewers, we presented ourselves as doctoral students and researchers, and emphasized that we are interested in the interviewee's individual experiences and opinions. I believe that through this, a confidential atmosphere was constructed and the interviewees were able to talk freely about their experiences. The interviewees presented personal and critical views concerning the topics at hand, which indicates that we achieved a trustful relation with them (Gertsen \& Søderberg, 2011).

In addition to the production of the qualitative data, a researcher also has a very active role in the subsequent analysis. First, it should be acknowledged that we did not let the "voices of the field" speak entirely for themselves in our analyses; we chose the quotes according to our criteria of importance from the interview transcripts (Gertsen \& Søderberg, 2011). Thus, much of what the interviewees have said is not covered in the articles, producing only one "entry point" to the extensive interview material. However, we discussed the research findings with informants in various workshops and had informal discussions with company representatives throughout the process. These "member checks" (Lincoln \& Guba, 1985) provided us with an opportunity to gain more insight to our findings and to test whether the research participants recognized our capturing of their world (Welch \& Piekkari, 2017). Nevertheless, one cannot claim that the 
reported interpretation is the only possible one, but it presents one way of interpreting the data. All references to empirical data are the results of interpretation and incorporate an understanding of how the researcher plays a role in the social construction of "knowledge". Through a careful account of the data analysis in each article, however, we sought to be explicit about the process through which we achieved the particular interpretations. 


\section{Article summaries and results}

In this section, I summarize the research objectives and findings from the four original publications. Following the summaries, I will discuss how the results contribute to the research questions defined in the beginning of this dissertation through integrating the results from the four articles under each research question.

\subsection{Article I: Rethinking the Control-Freedom Paradox}

Article I examines when and why managerial efforts to support the creativity of innovators lead to adverse motivational effects. The article focuses on how employees make sense of managerial efforts to further innovative behaviour, and particularly on how they make sense of managerial efforts to support creative freedom. Moreover, the study addresses how management justifies the methods employed and how the use of the specific methods results in adverse effects. The study draws on qualitative interview material from four large organizations operating in established industries.

The findings show how the innovators in the case companies demonstrated and articulated a strong creative identity and valued the ability to engage with ideas they found personally interesting. However, they did not report motivational struggles in fitting this together with serving organizational benefit. Rather, innovators experienced organizational benefit as an important motivational driver. Innovators criticized management for not sharing sufficient information with them with respect to organizational benefit so that they could direct their efforts accordingly. For the innovators, it was important to know that their ideas would be utilized in the business activity of the organization so that they would stay motivated in their development work. The innovators felt that in their position, it was difficult to gain access to the kind of information that would allow them to feed the dual motivational drivers of their practice.

Even though maintaining a creative identity and pursuing organizational goals were not conflicting forces for the innovators, managers operated under the assumption that they would be. Hence, they attempted to nurture the motivation of the innovators by protecting them from having to consider organizational 
benefit, and perceived this as protecting innovators from "organizational constraints”. Managers explicitly stated that they should protect innovators from "business realities" so that these constraints would not hamper their creativity and that they would feel free to experiment with radical ideas. The objective to keep creative ideation and organizational objectives separated was also reflected in the idea management systems and ideation labs whose purpose was to encourage "innovation without boundaries". In these systems, employees were expected to submit and experiment their ideas, and management was responsible for evaluating their fit with company objectives. While the goal was to communicate that free ideation is accepted and desired by top management, and innovators were encouraged to have fun when innovating, the lack of the link to strategic objectives prompted innovators to question the meaningfulness of the activity. Innovators expressed their frustration with the fact that they were not able to tailor their ideas to the needs of the company, which would also make the ideas more likely to be accepted and implemented.

The managers saw that free, fun structures were more likely to boost the innovators' motivation and that communicating business requirements early on would go against the core premise of creative freedom. Accordingly, managers were focused on harvesting ideas from innovators and did not see a need to share their knowledge with the innovators. Through these measures, they unintentionally ended up creating contrary motivational effects for the support efforts and left the innovators experiencing their creative freedom as being restricted. Moreover, innovators wondered how innovation activity could be a priority in the organization if links to the actual business were not visible. When innovators were protected from considering organizational interest, they perceived themselves as being assigned to "playing on a preassigned sandbox". This position was in stark contrast with their professional identities as creative individuals, which included the objective to contribute to the success of the organization.

\subsection{Article II: Competing narratives of suggestion system change}

The second article focuses on change narratives of three employee groups-responsible managers, evaluators and suggestion makers-who were involved in a suggestion system change in a large organization operating in the oil refinery business. The goal of the change under study was to increase employee motivation to submit suggestions by developing a more efficient procedure for their assessment. Moreover, the change involved an alteration of the distribution of responsibilities in the suggestion process. The purpose of the study was to explore how the changing responsibilities, as well as the goals and consequences of the change, were constructed in the employees' change narratives. The narratives of the three employee groups differed in terms of the main goals of the change process, the influence on employee innovative activity of the change, as 
well as the positioning of the different actors in terms of responsibility in the process.

For the responsible managers who worked in the corporate administration and oversaw maintaining the suggestion system and training employees in its use, the change would increase the quantity and quality of suggestions through deeper and more active engagement of suggestion makers. This would be achieved through the newly implemented IT system that supported the adoption of a new modus operandi, which entailed the redistribution of the responsibilities in furthering the suggestions in the system, as well as an increase in the transparency of the evaluation process. The responsible actor for the goals of the change to materialize was, in the managers' narrative, the suggestion maker. The redistribution of responsibility was further legitimized through referring to the earlier system, in which the role of the suggestion makers was considered passive while the commentators and evaluators worked to advance the ideas. Moreover, it was constructed as an opportunity for suggestion makers to advance their ideas and improve their work. The change would improve the fairness of the system, since the highest reward would be increased by $20 \%$ and was constructed as a motivating factor for suggestion makers by responsible managers. The change in the system would thus encourage a proactive role among suggestion makers and collective responsibility in advancing ideas through commenting others' suggestions in the system.

For evaluators, i.e. the middle managers who oversaw the evaluation of the suggestions in their respective divisions, the purpose of the change was to enhance the quality of suggestions. In the evaluators' narrative, the change was constructed as reducing their workload as suggestion makers would make more thorough descriptions of their ideas to the system, and additionally, through joint discussion in the system, solve possible technical issues or other questions. Speeding up the process and increasing the quality of the suggestions, through the active engagement of suggestion makers in the development of each other's ideas, were thus the primary objectives for the change from the evaluators' perspective. Contrary to the responsible managers' narrative, increasing the number of suggestions was not included in the suggestion evaluators' narrative, as the current level had already proven difficult to manage. The evaluators envisioned a system where they would only need to make the final go/no go decision once the idea had been thoroughly described and discussed by suggestion makers and experts in the system without the involvement of evaluators.

The narrative formulated by suggestion makers implied that the change would facilitate the evaluation process, and thereby provide the suggestions with faster treatment. Submitting ideas to the online platform was constructed as laborious compared to the possible rewards, and the responsibility for making the profit calculations of the suggestions was seen as residing at the higher organizational levels. The submission of the suggestions to the system was already in itself a significant effort, and requirements for further investment were considered uneven from the perspective of the potential reward. While the employees portrayed themselves as development oriented, the lack of enthusiasm towards the renewed system was justified by drawing on their sense of fairness. Although 
the earlier suggestion system had not been considered as efficient or exciting, the employee narrative portrayed the new system as including several threats to fairness, as it required more effort than the previous system, and the openness of the system was risky because somebody might hijack their ideas. Moreover, the potential threat to fairness was reflected in the motivational struggles related to the reward policy of the suggestions. While money was constructed as a central driver for innovative efforts, the modesty of the rewards and the uncertainty of a suggestion being accepted were also constructed as demotivating. Interestingly, however, the higher the level of the reward, the less motivating the monetary compensation was constructed. While the maximum reward was constructed as an appealing amount of money, demotivation resulted from the proportionally larger gains that the company would acquire by implementing the improvement ideas to the production process.

The study illustrates how each group constructed a different version of the changing suggestion program and how individuals were differently positioned in terms of the responsibilities in advancing the change in these accounts. Moreover, it illustrates the identity struggles the suggestion makers faced as they constructed themselves as development oriented, identified with the immediate work group, and wished to contribute to the efficiency of their work processes. Simultaneously, however, because of their dis-identification with the organizational level goals, they constructed themselves as disengaged with development work.

\subsection{Article III: Contradictory argumentations of spatial change}

The purpose of this study was to explore managers' and employees' rhetorical evaluations of a spatial organizational change. The empirical material of the study comprised of in-depth semi-structured interviews conducted in a single large company operating in the field of broadcasting. The findings of the study show how the actors of the organization spoke about, supported and contested a transformation from a traditional single-room office to an open, multi-space office. More specifically, the study illustrated how the concepts of encounters, creative work and innovativeness were used for opposite purposes, for example, to support and contest the change. The use of the commonplaces to either support or contest the change were tied to the speaker's organizational position.

The responsible managers supported the change and evaluated it positively, whereas the employees contested the change and predominantly evaluated it negatively. The responsible managers constructed the objectives of the change as being coupled with current and future work practices and needs, whereas the employees constructed the objectives of change as being decoupled from current work practices. Thus, the responsible managers and employees had not only different temporal orientations but also different ways to speak about what "real" work is like and what the change will result in. In addition to the contradictory rhetorical resources between the employee groups, the responsible managers 
justified the change through two simultaneous but completely different rhetorical resources: desired change and coercive change. The pursuit towards innovativeness was desirable, but also enforced to the organization by current changes in the society. In the societal talk, working life is depicted as changing radically in the future, following technological changes. Generally, this development was depicted as an unavoidable trajectory and something to which the organization naturally needs to react. Responsible managers depicted the changes in working life and the media field as a "fact of life" that cannot be ignored. The change must take place because the society and the working life is changing, which requires collaboration, innovativeness and flexibility.

With respect to the commonplace of encounters, the responsible managers and the employees produced opposite arguments. In employee talk, encounters and innovativeness were not constructed as belonging to the sphere of work, but as something external to it, and were even viewed as a threat to productivity. For managers, on the other hand, encounters denoted a central characteristic of a future work mode that would result in increased innovativeness. The change into an open office space would bring about mobility which results in encounters, and through this, the change was legitimized in the managers' talk.

Throughout the data, managers interchangeably used the concepts of creativity and innovativeness when justifying the need to increase openness and interaction between employees. Thus, innovation and creative work were not constructed as separate activities in their talk. Creativity was, in the managers' language, depicted as requiring openness and teamwork, which was restricted by the current office setting. The existing old office setting was problematized and evaluated negatively as a hindrance to a sense of communality, and therefore, creativity, by referring to corridors and cubicles as creating isolation. In the employees' talk, on the other hand creative work was distinguished from innovation. Innovation denoted collaboration and interaction, while creative work was depicted as requiring concentration and solitude, which would be hampered in open settings.

The responsible managers and the employees constructed the change in a different manner and employed contradictory rhetorical resources. However, their rhetorical resources drew from the same commonplaces. Although the employees and the managers shared the idea of innovativeness as a collaborative activity facilitated by serendipitous encounters, the consequences of increased innovativeness were argued in contradictory ways. Thus, the anticipated materialization of an innovative organization culture in the daily practice of the organization was used for supporting and resisting the change. Similarly, the commonplace of creativity was employed to resist the change by the employees, whereas the responsible managers used it to justify the transformation. Interestingly, employees used footing-which means that they spoke on behalf of other people when resisting the change-and thus withdrew themselves from resisting the change directly themselves. 


\subsection{Article IV: Program group's construction of context}

Article IV explores meeting discussions of a project group in a broadcasting corporation whose purpose was to translate the goals set for a change in the physical, virtual and social work environments into action plans and activate the operational level to implement the plans. The data is comprised of altogether nine project group meetings. The goal of the change in question was to reduce costs by making the use of the facilities more efficient, facilitate interaction between units and thereby enhance innovativeness through increased interaction between people and a new mindset concerning collaborative practices. The study explored how the members of the temporary project management group negotiated the scope of its activities through constructing a shared understanding of its operational context. The results of the study demonstrate the discursive patterns through which the members of the organization were portrayed as living in different times. These patterns were employed to construct a dualistic organization in which nominated change makers were modern and had an orientation to the future, whereas other members of the organization were described as oldfashioned people who were not willing to give up their old routines. The discursive patterns employed drew upon the organizational context in which the program group operated.

The findings show how the group formulated the organizational context of the change through two dimensions, temporal and hierarchical. The program group saw itself as living in the modern world with an understanding of how the organization should change in order to keep up with the development of society, become innovative and be an ideal place to work. However, the group saw the majority of the employees as being "stuck in the past" (not understanding that a traditional office space is outdated and valuing the old office setting), and therefore resisting change. Moreover, the management level was mainly depicted as having a past temporal orientation and supporting the employees' past thinking, thus hindering the execution of the change plans. Drawing on this, the top management was depicted as not understanding the relevance of the change nor understanding how alarming the organizational situation would be if the change would not take place. Line managers, on the other hand, were depicted as fleeing from the managerial responsibility to lead their teams to change. Thus, the program group pictured a gap in leadership with respect to the change program. This produced an interesting context for the program group, as they did not see themselves as having the hierarchical authority to act as the figureheads of the change. However, they saw the change as a necessity for the organization and considered themselves the only organizational actors with the knowledge required to push the change in the right direction.

The categorization as future-oriented entailed the idea of willingness to change, whereas a past orientation was linked to routinized activity. By categorizing the organization as past-oriented, the group was able to concretize and make sense of the resistance toward the transformation. When the group perceived strong resistance, its attitude toward the change program gradually shifted from enthusiasm to demoralization, and it more actively highlighted the 
need for managerial levels to step in and take responsibility for the implementation of the change. As for the hierarchical categorization, the program group members distanced themselves from responsibility for conducting change by referring to the functional roles of the permanent organization, i.e., managers' responsibility for leading their subordinates to change. They positioned top managers as those who should show the innovative vision and tell employees how they would work in the future, and middle management as those who were responsible for the operational change. The group refused to be involved with the vision, but their role was to convince the top management about the necessity of the change and understand the future vision, transferring their preliminary implementation tasks to the middle managers. Thus, at the practical level, the group limited its responsibility to communication and legitimization tasks.

\subsection{Summary of the results}

While each of the articles had their specific research questions, together they construct an answer to the three overarching research questions of the thesis. I defined the main research question of the thesis as follows: How, and with what consequences, do managers and employees discursively construct conceptions of innovativeness? I approached this through three sub questions: 1) What kinds of innovative subjectivities are constructed in the man-agerial discourse of innovativeness?; 2) What kinds of meanings are ascribed to innovativeness by employees and how do they relate to the managerially imposed innovative subjectivities in their accounts?; 3) What kinds of pragmatic consequences do the subjectification efforts have on the innovative pursuits initiated by the managers?

The managerial discourse produced a particular ideal of innovativeness by justifying the practices through which innovativeness was supported, which was drawn upon in the micro-level discourse conducted by employees. The results of this dissertation show that organizational innovativeness pursuits are ripe with struggles over subjectivity, as the managerially imposed ideal of innovativeness is not congruent with the employees' innovative identities. This, again, results in resistance of the managerial hegemony, with practical consequences. Next, I will integrate the findings from the separate studies under each research question. Table 3 summarizes the overarching results of the study. These include the antecedents of innovativeness and the ideal innovative subject portrayed in the managerial discourse, and employee innovative identity and form of identification with the managerial discourse.

\subsubsection{Construction of the innovative subject}

The first research question explored what kinds of innovative subjectivities were constructed in the managerial discourse on innovativeness. The results illuminate the premises based on which the managers sought to increase innovativeness, and based on which particular innovative subjectivities were constructed 
in the managerial discourse. I have identified four types of ideal innovative subjects from the Articles, and labelled them as "free radical", "proactive ideator", "social butterfly" and "future oriented pioneer". These labels reflect the primary feature of the managerial ideal of innovative behavior in each study.

In Article I the managers constructed the innovators as requiring freedom from business considerations. This was reflected in the managerial talk, but also in the organizational structures such as idea management systems that separated the supply of ideas from the evaluation processes as well as the ideation labs or "play structures" that invited employees to freely experiment on their ideas without concrete links to corporate strategy. These measures were justified in the managerial discourse by drawing on the idea of creativity, and thus innovativeness, as thriving under conditions with limited restrictions. Thus, the pursuit for radical ideas that are not captive of the current business and its restrictions produced a subject position of a "free radical", whose creativity blossoms when organizational constraints are removed.

In Article II, on the other hand, the improvement of the suggestion scheme was constructed as relying on the change in the suggestion practice of the suggestion makers, who were expected to take more responsibility of the development of their ideas. This was also reflected in the new IT platform for suggestions, which allowed for more active participation on behalf of the suggestion makers. Thus, the managerial discourse on increasing the flow of ideas through the renewed suggestion system constructed a new kind of subject position, namely a "proactive ideator" who develops and furthers ideas and, on top of that, engages in joint development of others' ideas.

In Article III, the managerial discourse associated innovativeness with openness, creativity and encounters. The entire organization was constructed as entering a new form of organizational culture, which supported the innovativeness of its employees. Innovativeness was constructed as a social phenomenon in which the diversity of knowledge and know-how was of crucial importance. Here, the transformation from the single room office layout, which hindered creativity by isolating individuals to their foxholes, to the open plan office favorable for encounters, constructed an innovative subject position of a "social butterfly" who crosses organizational boundaries by engaging in spontaneous ideation with a random passerby.

In Article IV, the innovativeness discourse produced by the project management linked innovativeness with a positive attitude towards change, and the organization was divided into those who lived in the past and those who held a future orientation. Those who lived in the past were constructed as hindering the change towards organizational innovativeness, whereas those who were able to see to the future and change could follow the innovative vision. Here, the discourse of the project group produced an innovative subject position of a "future oriented pioneer", who acknowledges change toward innovativeness as a prerequisite for organizational survival. 


\subsubsection{Responses to subjectification}

The second research question focused on the employee perspective, exploring the kinds of meanings employees ascribe to innovativeness, and asked how they respond to the subjectification of the managerial discourse.

In Article I, the employees constructed themselves as having an innovative identity, which means that they were naturally looking for development ideas and were motivated by the idea that they could contribute to the organizational success. Thus, consideration of the business goals was a central dimension of development work and innovativeness. Therefore, the innovative identity of the employees conflicted with the managerial ideal of innovativeness, which highlighted freedom from organizational constraints. The R\&D engineers constructed themselves as highly skilled technological experts, but they did not identify with the subject position of free radical, which undermined their capability of contributing to organizational goals. While identifying themselves with the organizational pursuits to enhance innovativeness, and while contributing to the benefit of the organization, the employees did not identify themselves with the position provided in the managerial discourse. Thus, following Elsbach's (1991) categorization of various modes of identification with organizational discourse, I have labelled this as schitzo-identification.

In Article II, the employees constructed themselves as development-oriented individuals rich in ideas. However, they did not identify with the position of proactive ideator constructed in the managerial discourse. For them, idea creation primarily denoted the submission of ideas to the system if a suitable idea would cross one's mind. The active engagement in idea development, responsibility of one's idea, as well as contribution to collective idea processing-characteristics of the proactive ideator-were not included in employees' constructions of suggestion activity. The employees legitimized their dis-identification (Elsbach, 1991) with the managerially imposed subject position by drawing on their sense of fair distribution of effort and benefit. The perceived imbalance of effort and benefit prompted struggles over identity. The employees constructed themselves as development-oriented and willing to contribute for the benefit of the work group, but at the same time positioned themselves as exploited by the organizational system and therefore demotivated to engage in organizationally significant ideation.

In Article III, the employees' construction of innovativeness differed from that of managers with two respects. First, while managers used creativity and innovativeness interchangeably, employees made a distinction between these concepts. In employee talk, creativity was work that took place in solitude, whereas innovativeness was collaborative. Second, while managers used increased innovativeness as a positive outcome in order to support the change, employees used innovativeness as an outcome that would have negative consequences for actual work. Drawing on these conceptions of creativity and innovativeness, employees dis-identified (Elsbach, 1991) themselves with the subject position of social butterfly, since spontaneous encounters were, in employee narratives, a hinderance to real creative work. 
Article IV is slightly different from the other articles because it does not portray a similar management vs. employee dichotomy. Nevertheless, identity struggles vis-a-vis innovativeness can be identified. While the project group constructed themselves as future-oriented and positive towards change, thus holding an innovative mindset, they refused to portray themselves as the supporters of the ideology within the wider organization. They did not position themselves as the figureheads of the change but instead highlighted their role as process owners, and the project group shifted the responsibility to top management. Thus, their identification with the innovative subjectivity produced by themselves represents a schizophrenic form of identification (Elsbach, 1991).

\subsubsection{Pragmatic consequences}

The third research question explored the pragmatic implications of the employee responses to the managerial pursuits to control their innovative identity. Within all the articles, employees had difficulty relating to the managerial ideals of innovativeness. In Article I, the managerial approaches were constructed as restricting the innovators' capacity to engage in innovative activity. Here, the strategy to separate business considerations and creative work was constructed as creating a sense of constrained freedom and a lack of meaningfulness of innovation efforts. This again was constructed as resulting in both unsuccessful efforts to engage employees in innovation and inertia in development efforts.

In Article II the struggle between the managerial ideal of how the suggestion system would work and the suggestion makers' identity narratives was manifest in the way in which the different employee groups positioned themselves outside the realm of responsibility, in terms of pursuing the change and thus increasing innovativeness. This produced an "agency void" in which no one was in charge of ensuring the acceleration of the suggestion process.

In Article III, the managerial ideal of the innovative organization and the subjectivity of social butterfly was used as a means to resist the change in the office setting. Here, the employees legitimized their opposition towards the organizational change by drawing on their conceptions on creativity and innovativeness. While the spatial change was taking place regardless of employee opposition, dis-identification with the subject position of social butterfly allowed the employees to legitimize their withdrawal from the principles of the new organizational culture.

Article IV shows how the polarization of the organization to future-oriented individuals (those with an innovative vision) and those who hindered the change, were used to construct the organizational context in such a way that the project group was able to legitimize its role as an onlooker in the change process.

To conclude, the study has identified ways in which managerial discourse construes innovativeness and how employees respond to these constructions. Moreover, the study has unveiled the plurality of meanings related to innova- 
tiveness and the identity struggles underlying organizational innovation pursuits. In the next section, I will discuss the contributions of these results, reflecting on prior literature. 
Table 3. Summary of results

\begin{tabular}{|c|c|c|c|c|}
\hline & \multicolumn{2}{|c|}{ Managerial discourse } & \multicolumn{2}{|c|}{ Employee discourse } \\
\hline $\begin{array}{l}\text { Arti- } \\
\text { cle }\end{array}$ & $\begin{array}{l}\text { Conditions that } \\
\text { facilitate inno- } \\
\text { vative activity } \\
\text { as defined in } \\
\text { managerial talk }\end{array}$ & $\begin{array}{l}\text { Ideal innovative } \\
\text { subject }\end{array}$ & $\begin{array}{l}\text { Innovative } \\
\text { identity of } \\
\text { employees }\end{array}$ & $\begin{array}{l}\text { Identification with } \\
\text { the managerially im- } \\
\text { posed subject posi- } \\
\text { tion }\end{array}$ \\
\hline 1 & $\begin{array}{l}\text { Freedom and } \\
\text { protection from } \\
\text { organizational } \\
\text { constraints, "play } \\
\text { structures" that } \\
\text { facilitate idea- } \\
\text { tion. }\end{array}$ & $\begin{array}{l}\text { Free radical- } \\
\text { longs for opportuni- } \\
\text { ties to engage in } \\
\text { random ideation } \\
\text { without limits. }\end{array}$ & $\begin{array}{l}\text { Highly skilled, } \\
\text { development } \\
\text { oriented tech- } \\
\text { nological ex- } \\
\text { perts with mo- } \\
\text { tivation to } \\
\text { contribute to } \\
\text { organizational } \\
\text { success. }\end{array}$ & $\begin{array}{l}\text { Schitzo-identifica- } \\
\text { tion-development ori- } \\
\text { entation and commit- } \\
\text { ment to organizational } \\
\text { goals, while construct- } \\
\text { ing the free radical po- } \\
\text { sition as curbing one's } \\
\text { creativity and thus cre- } \\
\text { ating demotivation. }\end{array}$ \\
\hline II & $\begin{array}{l}\text { Optimal IT plat- } \\
\text { form and reward } \\
\text { structure which } \\
\text { enables and mo- } \\
\text { tivates extra-role } \\
\text { innovativeness. }\end{array}$ & $\begin{array}{l}\text { Proactive ideator- } \\
\text { proactively devel- } \\
\text { ops and furthers } \\
\text { ideas and engages } \\
\text { in joint develop- } \\
\text { ment of others' } \\
\text { ideas. }\end{array}$ & $\begin{array}{l}\text { Strong do- } \\
\text { main-specific } \\
\text { expertise } \\
\text { based on ex- } \\
\text { perience, mo- } \\
\text { tivation to im- } \\
\text { prove work } \\
\text { processes. }\end{array}$ & $\begin{array}{l}\text { Schitzo-identifica- } \\
\text { tion-strong commit- } \\
\text { ment to work group } \\
\text { and improvement of } \\
\text { working conditions, or- } \\
\text { ganizational innova- } \\
\text { tion pursuits seen to } \\
\text { unequally benefit the } \\
\text { top honchos. }\end{array}$ \\
\hline III & $\begin{array}{l}\text { Open office set- } \\
\text { ting and shared } \\
\text { spaces, which } \\
\text { facilitate opportu- } \\
\text { nities for social } \\
\text { encounters } \\
\text { across organiza- } \\
\text { tional borders. }\end{array}$ & $\begin{array}{l}\text { Social butterfly- } \\
\text { open mindset, en- } \\
\text { gages in casual } \\
\text { ideation with pass- } \\
\text { ersby, all employ- } \\
\text { ees potential inno- } \\
\text { vators. }\end{array}$ & $\begin{array}{l}\text { Strong crea- } \\
\text { tive identity, } \\
\text { innovative- } \\
\text { ness distin- } \\
\text { guished from } \\
\text { creativity. }\end{array}$ & $\begin{array}{l}\text { Dis-identification legiti- } \\
\text { mized by constructing } \\
\text { innovativeness as dis- } \\
\text { turbance to real work. }\end{array}$ \\
\hline IV & $\begin{array}{l}\text { Top manage- } \\
\text { ment's commit- } \\
\text { ment to change, } \\
\text { future oriented } \\
\text { mindset among } \\
\text { employees. }\end{array}$ & $\begin{array}{l}\text { Future oriented vi- } \\
\text { sionary-under- } \\
\text { stands the neces- } \\
\text { sity of change for } \\
\text { organizational sus- } \\
\text { tainability. }\end{array}$ & $\begin{array}{l}\text { Future ori- } \\
\text { ented with the } \\
\text { lack of au- } \\
\text { thority to fur- } \\
\text { ther the inno- } \\
\text { vative vision. }\end{array}$ & $\begin{array}{l}\text { Schitzo-identifica- } \\
\text { tion-refusing to adopt } \\
\text { responsibility while } \\
\text { constructing oneself } \\
\text { as the only party with } \\
\text { required knowledge. }\end{array}$ \\
\hline
\end{tabular}




\section{Discussion}

In this study, I was interested in the ways innovativeness was constructed in managerial discourse and how employees responded to managers' attempts to engage them in innovation. I was particularly interested in the subject positions imposed on employees by the managerial discourse, and how employees identified themselves with these subject positions. Through this, I explored innovativeness as a managerial control mechanism. In academic research, innovativeness is conventionally treated as an objective feature of organizations and individuals. Scrutinizing it as a socially constructed phenomenon, however, has unveiled the fluidity and fuzziness of the construct. This becomes evident in the variety of ways in which innovativeness is constructed in the meso-level and micro-level organizational discourse (Vaara, 2010), and the way in which it is used to legitimize or resist organizational change. In the following, I will discuss the findings of this study, reflecting on prior literature. In addition, I will discuss the limitations of the study and propose future research directions that I consider interesting in the light of the findings.

\subsection{The multifaceted discourse of innovation}

As discussed in the beginning of this thesis, innovation has not always been highly regarded. For centuries, it held a strongly negative connotation, and only in the 1960's it became a measure for technological progress (Godin, 2012; Fougére \& Harding, 2012). Today, innovativeness is indisputably a desired characteristic, and the societally hegemonic discourse constructs it as an indispensable attribute of nations, organizations and even the individual.

The present study shows how this macro-level innovation discourse was reproduced in the managerial talk as managers constructed innovativeness as a necessity for organizational survival. This was used to legitimize the various practices and processes through which managers sought to stimulate employee innovativeness. Underlying the motivation to implement specific practices and processes was an understanding of how innovativeness is best supported and what an innovative individual is like. Managers referred to the "common knowledge" of innovativeness, for example, by stating that, "as we know, single office rooms do not support innovative behaviour," or, "discipline has an adverse effect on creativity." Simultaneously, the managerial talk constructed a particular form of ideal innovative subjectivity for employees. 
The micro-level discourse refers to employee meaning-making concerning the official innovation narratives promoted by managers. Employees drew from their conceptions of innovativeness and their self-positioning within the discourse when responding to the managerial methods for increasing innovativeness and justifications thereof. This resulted in identity struggles and resistance vis-à-vis the innovative efforts, as the innovative subjectivity imposed by managers was not congruent with the innovative identities of employees. In the context of innovation, the discourse filtered by management and adapted to the organizational context most likely competes with other constructions of innovativeness that individuals produce as they are exposed to the macro-level innovation discourse from various sources. The interplay between the different levels of the innovation discourse is illustrated in Figure 2, which is an adaptation of Vaara's (2010) framework on the multifaceted nature of organizational discourse.

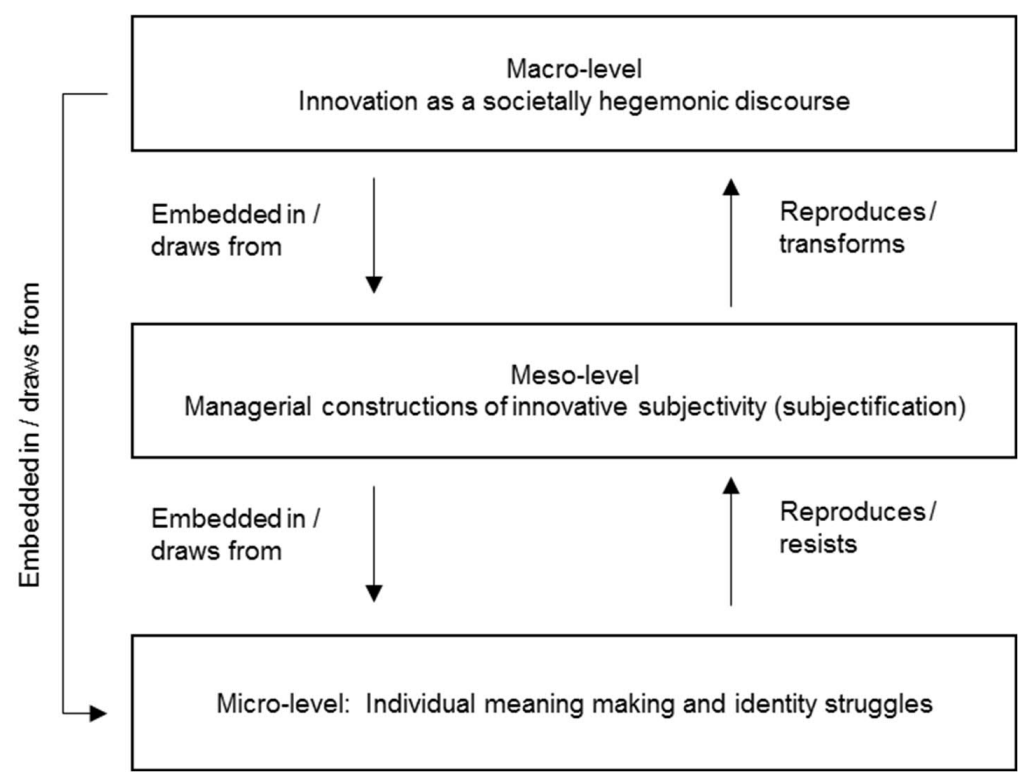

Figure 2. The multifaceted discourse of innovation, adapted from Vaara (2010)

By exploring innovativeness through the discursive lens in the organizational context, the present study has sought to unveil the controversial nature of innovativeness in the everyday organizational discourse, and the ways in which managerially imposed innovative subjectivities are contested by employees. Moreover, scrutinizing innovativeness as a managerial control mechanism through which particular innovative subjectivities are imposed on employees, the study has discussed the ways in which managers seek to regulate employee identities towards innovative behavior and how employees resist such pursuits. Thus, the present study complements earlier work, which has focused on the macro-level discourse, and points out the biased nature of the discourse (Kimberly, 1981; Sveiby et al, 2012) and the tendency of the contemporary innovation discourse 
to neglect the context-specific nature of innovation (Anderson, 2014; Anderson \& King, 1993). Although these discussions bring up interesting features of the dominant notion of innovation, they have remained at the macro level of analysis, and the illumination of the subjectification tendencies and the related power effects operating at the micro level in the form of, e.g. identity struggles, has remained outside the scope of these discussions.

While the societal discourse of innovation has been under scrutiny by a few scholars, linguistic approaches have been rarely employed in studies addressing innovation in organizations. Earlier work has viewed innovation narratives as the production of shared organizational sensemaking that enable knowledge sharing during innovation processes (Bartel \& Garud, 2009; Deuten \& Rip, 2000), addressing specific innovation trajectories in organizations. The focus has been on official, shared narratives, and thus on the meso-level discourse on innovation. The present study has complemented these views by elucidating the plurality of ways in which employees reproduce and contest the official narratives of organizations. Moreover, the present study shows how the pursuit towards innovativeness is used to justify organizational change and construct organizational hierarchies. The vagueness of innovativeness, combined with the positive connotations it generally holds, makes it a rather versatile construct to be employed for different purposes.

By addressing the plurality inherent in innovation, this study has similarities with those exploring innovation from the practice perspective. Practice scholars, who have criticized the tendency of mainstream innovation management literature to depict innovation as an unambiguous and linear process, have illuminated the complex and emergent processes through which idea development takes place at the grass roots level (e.g. Brown \& Duguid, 1991; Garud et al, 2011; Lempiälä, 2011). The findings of the present study are particularly parallel with the observations made by Lempiälä (2011), who pointed out that the managerial ideals of innovation processes, or the front stage of innovation, were built on understanding that differed from the premises of the back stage innovation processes. Lempiälä's (2011) study showed that the managerial ideals of a linear and predictable process, promoted by various idea management structures, were in stark contrast with the messy collaborative praxis through which ideas unfolded in actuality. In a similar vein, the present study shows how the managerial ideals of the innovative subjectivity were discrepant from employee constructions of innovativeness. However, rather than addressing the praxis of innovation, the present study has narrowed its focus to the level of discursive constructions of innovativeness and the identity struggles related to these.

Moreover, the present study has complemented work which has explored sensemaking in the context of innovation. Studies by Bechky (2003), Dougherty (1992) and Dougherty et al (2000) demonstrated that different occupational groups hold different interpretive frames, thus their views on how to further development processes differ which may hinder the process. In these studies, hindrance to the innovation processes resulted particularly from the lack of mutual contextual understanding and shared professional language between organizational units. In the present study, the discrepancies were rooted in the 
differing constructions of innovative subjectivity. Thus, the "hindrance" to innovation observed was, in a sense, more fundamental in nature as it concerned the constructions of innovativeness as such, and the questions of who was an innovator in the first place and what this position entailed.

Next, I will elaborate in more detail on how the findings of the present study contribute to our understanding of innovativeness as an identity regulation mechanism and employee responses to managerial subjectification.

\subsection{Regulating innovative identities}

The process of subjectification aims to constitute identities in organizations in such a way that employees manage themselves on behalf of organizational interests (Fleming \& Spicer, 2014). Thus, through the disciplinary power of managerial discourse, organizational actors engage in self-regulation, whereby they embody the directives of the organization and enforce it upon their identities. In the context of innovation, earlier research has identified identity regulation as a paradoxical challenge, as managers strive to control creative employees to adopt a business mindset, which would ensure that employees target their creative efforts towards organizationally meaningful goals. Here, the business practicalities are considered contradictory (paradoxical) with free, creative pursuits of innovators, and thus requiring ongoing identity regulation from the part of management (Andriopoulos \& Lewis, 2009; Gotsi et al, 2010).

In the present study, the dynamic was reversed, as managers sought to regulate employee identities towards more creative behaviour and thereby stimulate organizational innovativeness. The issue was thus not about herding limitless creativity towards organizational goals, but imposing a more creative identity on employees, and even deliberately freeing or even protecting them from business considerations (as was the case in Article I). Moreover, the facilitation of innovative behavior was not constructed as a paradoxical challenge that would require ongoing attention in the organizations studied, but instead it was approached as a rather simplistic challenge of increasing factors that were considered as correlating with innovativeness, such as freedom, responsibility, rewards and open office space.

While the organizations studied shared the same goal of increasing innovative behaviour among employees, the managers in different contexts approached identity regulation differently. In Article I, in which white collar R\&D engineers were encouraged to engage in radical innovation, the challenge constructed by managers concerned the facilitation of more creative behavior among engineers and less consideration of business realities. Managers considered this to be achieved through protecting employees from business considerations and creating space for free ideation, simultaneously producing the preferred innovative subjectivity of free radical. Thus, the appropriate work orientation in terms of innovation in managerial talk and methods highlighted the appreciation of constraint-free creativity, detachment from daily routines and self-determination. Control towards innovative behaviour was thus sought through accentuating the 
lack of control, which paradoxically created a sense of restrained autonomy among employees.

In Article II, on the other hand, the challenge constructed in the managerial talk was to increase ideation activity and commitment to advancing one's ideas. This was pursued by communicating increased responsibility and the requirement for more autonomous action from the part of employees, as well as adjusting the reward policy. Through this, the managerial discourse very explicitly produced the innovative subjectivity of proactive ideator by defining the roles and responsibilities of employees involved in the suggestion scheme. This subjectivity of proactive ideator was also constructed as natural and fair by drawing on the renewed reward policy, and thereby justifying the requirement of increased responsibility of suggestion makers.

Finally, in Article III, the challenge articulated by managers was to create an overall innovative organizational culture, and thereby engage all employees in becoming more innovative. This was pursued through increasing facilities for teamwork and the possibility of random encounters between organizational units through an open plan office and a collaborative mindset. The managerial discourse of shared space, cross-divisional collaboration and serendipitous encounters that would result in innovation produced an innovative subjectivity of social butterfly. In this context, the management also referred to the wider organizational context and the characteristics that are required from employees and organizations in order to survive in the future. Openness and encounters were constructed as key factors in ensuring the organizations' ability to attract future talent and survive in the increasingly competitive business landscape.

The findings of the present study suggest that in the context of innovativeness, identity regulation is difficult to achieve. Innovativeness does differ from the more traditional managerial control discourses with many respects. First, integration of innovativeness as part of the daily work responsibilities is difficult compared to, for example, total quality management, business planning or teamwork. For innovativeness, there are no instructions (as for e.g. TQM)-only guiding structures, or optimal conditions. Simultaneously, as earlier work has suggested, such structure can be interpreted differently (Lempiälä et al, 2017), and the optimal conditions may differ between contexts and individuals. Second, supporting innovativeness by managerial control runs, in a sense, counter to the very essence of innovativeness, which is associated with intrinsic motivation, serendipitous discoveries, unpredictability and fuzziness (see e.g. Austin et al, 2012). Third, employees may choose not to engage in innovative activity and yet do their job as required, because it would be against the ethos of innovativeness to enforce it upon individuals. Thus, the discourse of innovation is not as pervasive as, for example, the discourse of business planning (see Oakes et al, 1998).

Although the idea of the discourse of innovation as a managerial control mechanism is counterintuitive, through communicating, that innovativeness is accepted and desired within the organization; implementing structures that seek to facilitate such behavior, management indeed seeks to control employee behavior towards innovativeness. As observed in the present study, managers 
tackle this paradox of controlling people's behaviour towards innovativeness by stressing the acceptance towards innovative behaviour, and by seeking to create an organizational culture and set up organizational structures that encourage people to come forward with their ideas. However, as extra-role innovation is voluntary in nature, identification with the innovative subjectivity remains an option for employees.

The findings of the study show how, despite significant efforts by management, the highly "liberal regime of control" (Fleming \& Spicer, 2006:35) vis-àvis innovation attempted by managers failed to stimulate innovative behavior among employees. The cultural domination of the macro-level innovation discourse (Vaara, 2010) indeed seems to drive organizations to adopt the "most appropriate" structures and practices for supporting innovative behavior among employees. The ways in which these structures and practices were reproduced and interpreted in the organizational context, however, resulted in disengagement from the managerial ideals among employees. The interesting discrepancy here is that many of the employees studied constructed themselves as innovative individuals, motivated to engage in development work, thus identifying themselves with some kind of general concept of innovativeness and development orientation. Next, I will discuss in more detail the manifestation of employee dis-identification with the managerially imposed innovative subjectivities.

\subsection{Resisting the managerial ideal of innovative subjectivity}

The hegemonic status of innovativeness was reflected in the way in which the majority of the interviewees for this study portrayed themselves as having a positive attitude towards change and development and constructed themselves as innovative individuals. The capability of doing development work was constructed as a desirable attribute, particularly in Articles I and II, and the change to a positive mindset was something that the majority of individuals strongly related to in their accounts in Article III. Moreover, the need to portray oneself as change oriented also became evident in the way in which individuals would distance themselves from resisting change and used footing (Goffman, 1987) in order to resist change "on the behalf of others". In addition, the ability to adopt an innovative vision was used to distinguish between those organizational members who were "stuck in the past" and those who had the capability to change and respond to future requirements, thus creating an arbitrary organizational hierarchy in Article IV.

However, although the majority of employees did construct innovativeness as a desirable trait and identified themselves as innovative individuals, the ways in which managers sought to control for such activity were contested. The notion that a managerial hegemony is always incomplete (Spicer \& Böhm, 2007) becomes very evident in the context of innovativeness. The results of the present study suggest that while at the societal level, the disciplinary power of the innovation discourse seems to work to the degree that organizations put significant 
effort into the pursuit of innovativeness, and people acknowledge innovativeness as a desirable attribute, employees find ways to contest the managerial reproduction of the discourse in the organizational context. Moreover, while innovativeness has conventionally been treated as an objective construct, the present study has shown that innovativeness is a highly dynamic concept, as individuals appropriate different meanings to it in their accounts. Therefore, a multitude of subjectivities within the discourse is available, and the managerial constructions of innovative subjectivity are easily contested.

While in earlier work on micro politics of resistance employees have been found to draw on other selves such as motherhood (Thomas \& Davies, 2005) or authentic self (Costas \& Fleming, 2009), when contesting managerial hegemonies, the present study showed that employees drew on their constructions of innovativeness and their sense of innovative subjectivity, which differed from that proposed by managers. Compared to other managerial discourses, innovativeness is widely established at the societal level, and it is produced as a personal attribute in addition to being a desired national and organizational characteristic. In addition, the innovativeness discourse is principally inclusive, unlike for example the strategy discourse, which creates organizational hierarchies and closes certain organizational groups outside of its realm (Mantere \& Vaara, 2008). The innovation discourse positions all organizational actors as potential innovators; however, the results of the present study suggest that the managerial discourse simultaneously defines a particular desired innovative subjectivity for the consumption of employees. In other words, while the managerial talk seeks to involve the entire organization in innovation, it produces a particular innovative subjectivity that employees may withdraw from if it is in conflict with their self-positioning in the realm of innovation.

In Articles I and II, innovativeness was not something completely new in the discourse of the studied organizations, but rather, management sought to influence the existing innovative identities in order to facilitate the development of more radical and organizationally significant ideas. In Article III, on the other hand, innovativeness was not an integral part of the existing organizational culture, but rather a new feature imposed by managers. Drawing on Elsbach's (1999) classification on levels of identification with organizational discourse, in Article III employees completely dis-identified with the managerially constructed innovativeness, whereas in Articles I and II, identification could be characterized as schitzophrenic. This means that employees were enthusiastic about development work and even committed to contributing to organizational success, or at least the work community. However, the employees did not identify with the subject position produced in the managerial discourse, which diminished their identification with the organizational innovation pursuits.

The results show that the ways in which employees identify themselves with the managerially proposed subject positions differs between different contexts and different professional identities. Schitzo-identification was particularly apparent in Article I, where R\&D engineers, for whom development work was indeed an integral part of their profession, dis-identified with the position of free radical. Here, the position of free radical, which had no contact to the business 
objectives, was in contrast with their identities as innovative developers with high levels of professional expertise and with their commitment to contribute to organizational success. Thus, the subject position of free radical was in conflict with the ethos of their professional practice as technology developers.

In Article II, on the other hand, the employees studied were blue-collar workers who constructed themselves as highly committed to the immediate work group and to the development of work practices, but were not committed to the overall organizational success. They drew a sharp distinction between the "top honchos" who would benefit from organizational success and themselves, and thus dis-identified with the position of a proactive ideator who would put significant effort in furthering one's ideas through the organizational system. For them, innovativeness was particularly linked to the development of work practices and not so much to the contribution of organizational success in the form of proactive development of radical ideas. In Article III, employees dis-identified with the subject position of social butterfly by constructing innovativeness as something outside the realm of real work and something that disturbs creative work. In this case, the employees did indeed agree with the managerial conception of innovativeness as a collaborative endeavor, yet, they were using this conceptualization to dis-identify themselves from innovative activity.

The results show how the majority of employees did not resist innovativeness as such, but instead the subjectivities constructed for them in the managerial discourse. However, instead of exercising their agency to claim more room for maneuver in the domain (Laine \& Vaara, 2007), employees in the present study discursively constructed themselves outside the realm of responsibility, and thereby resisted the managerial vision of innovativeness. To a large degree, studies focusing on micro politics of resistance in terms of the identity regulation strategies have reported ways in which employees dis-identify with the managerial discourse while still complying with it (Brown \& Coupland, 2005; Dick \& Cassels, 2002; Whittle, 2005). This study, on the other hand, shows how dis-identification-or schitzo-identification-with the ideal innovative subjectivity became manifest as withdrawal from responsibility to contribute to innovation pursuits.

This study echoes the findings that acknowledge employee agency to contest subjectivities imposed by managerial discourses (Laine \& Vaara, 2007; Thomas \& Davies, 2005; Trethewey, 1997). In the context of this study, the attempted corporate culture concerning innovativeness did not materialize because the attempted discursive practices and subjectivities did not "colonize employees' minds" (Fleming \& Spicer, 2003), even though they constructed themselves as innovative. Following Thomas and Davies (2005), the "looseness of meanings" around innovativeness allowed individuals to appropriate different meanings while reflecting their positioning within the innovation discourse. Therefore, the managerial identity regulation mechanisms for innovativeness were unsuccessful because they failed to harness the innovative identities of the individuals for the benefit of the organization. While the macro-level innovation discourse drives organizations to pursue innovativeness through particular organizational 
structures and practices-and thereby reproduce the ideal innovative subjectivity in the organizational context-employees exercise power through constructing competing innovative subjectivities and by drawing on those in their identity narratives.

\subsection{Practical contributions}

Organizations seek to enhance their innovativeness by introducing various structures and practices to support innovative activity among employees. The present study suggests that managerial approaches to increasing innovative behavior are often based on simplified assumptions concerning the drivers underlying such activity. The study shows how the ideal of innovativeness constructed in the managerial discourse was based on abstract concepts of encounters, creative freedom and future orientation. Constraint-free ideation platforms and play structures that were detached from the organizational objectives, as well as abstract talk about increased encounters, made it difficult for employees to identify themselves with such activity.

The notion brought up by Anderson et al (2014), that if something has been found to improve innovativeness an increase in that factor results in more innovativeness, is a common assumption underlying the discourse of innovation. The same assumption seems to operate in the organizations investigated in the present study with respect to creative freedom, responsibility and proactivity, as well as openness and collaboration. These "antecedents of innovativeness" were supported in the organizations, without the appreciation of the complexity underlying innovation, contextual differences and the multiplicity of ways in which innovativeness may be construed by different organizational actors. The results of the present study may help management to better understand and pay attention to the multiple ways in which employees respond to pursuits to enhance organizational innovativeness.

First, it would be important to understand how employees position themselves within the realm of innovativeness. Defining the innovative subjectivity by management does not necessarily work, because it may be in conflict with the innovative subjectivity defined by the individual, or the individual may not identify with innovativeness in the first place. Thus, as a practical approach, it would be important to build innovative practices more emergently from within the organization, thereby allowing employees to define for themselves their own innovative subjectivity. In one of the organizations of this study, an interviewee spoke of a development team they had established-even though it had nothing to do with the organizational change effort. Providing resources for such autonomously emerging initiatives, instead of trying to enforce people in idealistic externally imposed innovation structures, might be more effective. Thus, allowing for a more proactive role in defining the ways in which innovativeness is supported might work better than the setting up of systems and structures that assumingly increase innovativeness or that have been proved efficient in other contexts. 
Second, the results suggest that it would be important for management to be reflexive about their assumptions based on innovativeness. Seemingly fair reward structures, or constraint-free ideation platforms, may bear differing meaning for employees and may have adverse motivational effects for individuals. The study thus encourages management to be critically reflexive (Cunliffe, 2016) with respect to their established assumptions concerning the elements that support innovative behavior. Critical reflexivity refers to the critical examination of the assumptions underlying one's actions and the impact of those actions, as well as a greater awareness of different perspectives (Cunliffe, 2016). This means that managers should understand on what premises particular practices are employed and whether they are relevant for employees in the particular organizational context. In the present study, the practices employed were oftentimes justified by managers by saying that a particular approach has been found to relate to higher levels of innovativeness. Here, questioning the "common wisdom" of innovativeness would be useful, as building on it seems to result in the construction of innovativeness in too simplistic terms.

In order for employees to be able to identify themselves with organizational innovative pursuits, it is of paramount importance to be explicit about the objectives of innovative activities, and how they are related to the organizational goals in the particular context. Through innovation campaigns that remain detached from the context of work, the legitimacy of innovation can become questionable-particularly in cases where development work is already part of the formal job description.

Moreover, it would be important to understand that, although innovativeness would be rhetorically constructed in a similar fashion by different individuals, it does not mean that the underlying meanings would be similar. For some people, innovativeness may hold negative connotations. Therefore, for example, "increased innovativeness" as such is not necessarily a legitimate justification for organizational change; instead, too general of approaches may be considered as illegitimate and diminish the credibility of the managerial pursuits. Related to this, rather than labeling employees who contest innovation efforts as resistant, it could be useful to capitalize on their views in developing organizational methods for engaging employees in innovation instead of expecting them to "get it" in the end.

\subsection{Limitations of the study and future research directions}

The present study is based on a qualitative paradigm, in which the purpose is to describe, explain, and understand the meanings people have constructed about their world and experience (Denzin \& Lincoln, 2008, Merriam, 2002). Qualitative research always provides a limited view of organizations and the organizational processes, as the number of interviewees and the temporal scope during which the research is conducted is limited. However, the objective of qualitative research is to gain deep insights into phenomena under study and increase understanding of complex social processes (Van Maanen, 1997, Marshall, 1996). I believe that the present study has achieved this by exploring through in depth 
analysis how individuals make sense of their experience concerning organizational efforts to increase innovativeness, albeit some voices are most likely missing due to limitations of the data.

In qualitative research, generalizability concerns general structures rather than single social practices, which provide only one example of the structure (Gobo, 2007). This means that the results of qualitative research on social interaction can be generalized as possible practices (Peräkylä, 2011). Thus, similar kind of resistance towards innovation efforts as described in the present study would not necessarily take place in other contexts, but this study describes possible outcomes of managerial attempts to increase innovativeness. The study thus provides one way of understanding and explaining the difficulty of furthering innovativeness in organizations.

The findings of the present study are based on four individual sub studies that have been conducted in different organizational contexts and with different research orientations. While all of the sub studies dealt with attempts to further innovativeness, the perspectives taken in these studies did not primarily address the issue of subjectification and innovative identity. Rather, identity regulation and the related struggles emerged as a common theme from the studies and this perspective provided a useful lens for understanding the struggles concerning managerial pursuits to further innovativeness in the different contexts. Although the present study has explored only a handful of contexts and approaches to stimulating employee innovativeness, it suggests that significant differences exist in terms of how innovativeness is constructed within organizations, and that this seems to result in "struggles over subjectivity". The findings of the study thus highlight the need to further explore innovation at the level of individual meaning making in organizations.

This study has focused on exploring managerial attempts in established organizations to increase innovativeness through introducing new processes or practices. This has been a fruitful way to explore the managerial discourse of innovation and the counter discourses produced by employees. To understand the innovation discourse more broadly, however, it would be beneficial to study the discourse in different industries and maybe smaller, less hierarchical organizations. For example, studying perceptions related to innovativeness in companies that are engaged in innovative activity, but where it is not introduced as something external to the core task of the employees would most likely provide a different perspective to the phenomenon.

Although it is established that innovativeness is the result of a complex array of individual and contextual factors, the facilitation of innovativeness is approached in simplistic terms and particular antecedents for innovativeness seem to dominate the organizational discourse. As the present study has focused on the ways in which employees contest the managerial attempts, an interesting question remains concerning managers and the ways in which the discourse of innovation is reproduced in different organizations. Future studies concerning innovativeness could focus on exploring, why particular antecedents of innovativeness become accentuated in different contexts. Focus in more depth on the managerial perspective would allow researchers to explore the construction of 
their "innovative identities" and the ways they construct their position as facilitators of innovation.

The present study has attempted to shed light on the ways in which the innovation discourse is reproduced in contemporary organizations. In addition to the subjectification of the managerial innovation discourse, the findings of the present study indicate that innovativeness is used for other purposes as well, including legitimation of organizational change and construction of organizational hierarchies. As the present study is limited in breadth and scope to only a small number of large, established organizations, it would be interesting to analyse more systematically the use of the concept in different contexts. This would broaden our understanding of the various purposes for which innovativeness is used in organizational talk and the implications of these.

Finally, as much of the data collected in this study is comprised of interview material, it should be noted that the criticism towards managerial innovation efforts might, in some instances, also reflect an individual's willingness to portray oneself as an innovative individual. Through criticizing the managerial system, the informants were able to legitimize their passivity vis-a-vis the innovation efforts, and thus position themselves as innovative in front of the researchers. This would indeed reflect the strong legitimacy of innovativeness as an individual-level attribute, but in this case, the actual reasons behind passivity would have remained unaddressed. Thus, future research would benefit from capturing more naturally occurring discussions concerning innovation efforts under scrutiny. 


\section{Conclusions}

In the contemporary discourse of innovation, every organizational member is constructed as a potential innovator who is expected to contribute creative outputs for the benefit of the organization. This discourse is driving organizations to introduce structures and procedures through which the creative potential of employees can be most efficiently utilized. Earlier work on organizational innovativeness has built primarily on the realist ontology, seeking to identify cultural, structural and individual-level factors that correlate with innovative behavior among employees. The present study has brought a novel perspective to innovativeness by scrutinizing it as a culturally hegemonic discourse which legitimizes particular values, aspirations and modus operandi in the contemporary organizations. Following this, managers employ particular strategies in order to control the behavior of employees towards organizationally meaningful creative endeavors.

The objective of this study was to investigate the ways in which managers seek to enhance innovativeness and how they justify the given methods, as well as how employees respond to these efforts. One particular focus was on the subjectivities that were constructed in the managerial discourse and the ways in which employees related to these in their accounts. Based on the findings, the managerial approaches seem to draw on simplifications concerning the drivers underlying innovative behavior. Second, I identified the meanings that employees ascribed to innovativeness and the ways in which they responded to the subjectivities imposed by the managerial discourse. The findings showed that employees contested the managerially imposed subjectivities by drawing on their existing constructions of and identification with innovativeness. The fluidity and ambiguous nature of the concept of innovativeness enabled organizational actors to position themselves within the discourse in a multiplicity of ways in different organizational contexts. Finally, I showed how the managerial methods to increase innovativeness had a counterproductive influence on employee identification with organizational innovativeness. Innovation efforts driven by abstract notions such as creative freedom, encounters, collaboration, proactivity and future orientation resulted in alieanation from the organizational innovation pursuits by employees.

Based on the results I suggest that managers should critically reflect on their assumptions concerning the drivers of innovativeness. Moreover, I encourage managers to engage in dialogue with employees concerning innovation to understand its intricacies in their respective contexts. 


\section{References}

Abernathy, W. J., \& Clark, K. B. (1985). Innovation: Mapping the winds of creative destruction. Research Policy, 14(1), 3-22.

Alvesson, M. (1991). Organizational symbolism and ideology. Journal of Management Studies, 28(3), 207-226.

Alvesson, M., \& Kärreman, D. (2000a). Varieties of discourse: On the study of organizations through discourse analysis. Human Relations, 53(9), 1125-1149.

Alvesson, M., \& Kärreman, D. (200ob). Taking the linguistic turn in organizational research: Challenges, responses, consequences. The Journal of Applied Behavioral Science, 36(2), 136-158.

Alvesson, M., \& Robertson, M. (2016). Money matters: teflonic identity manoeuvring in the investment banking sector. Organization Studies, 37(1), 7-34.

Alvesson, M., \& Willmott, H. (2002). Identity regulation as organizational control: Producing the appropriate individual. Journal of Management Studies, 39(5), 619-644.

Amabile, T. M., Conti, R., Coon, H., Lazenby, J., \& Herron, M. (1996). Assessing the work environment for creativity. Academy of Management Journal, 39, 11541184.

Anderson, N., Potočnik, K., \& Zhou, J. (2014). Innovation and creativity in organizations: A state-of-the-science review, prospective commentary, and guiding framework. Journal of Management, 40(5), 1297-1333.

Andriopoulos, C., \& Lewis, M. W. (2009). Exploitation-exploration tensions and organizational ambidexterity: Managing paradoxes of innovation. Organization Science, 20(4), 696-717.

Austin, R. D., Devin, L., \& Sullivan, E. E. (2012). Accidental innovation: Supporting valuable unpredictability in the creative process. Organization Science, 23(5), 1505-1522.

Balogun, J., Jacobs, C., Jarzabkowski, P., Mantere, S., \& Vaara, E. (2014). Placing strategy discourse in context: Sociomateriality, sensemaking, and power. Journal of Management Studies, 51(2), 175-201.

Bartel, C. A., \& Garud, R. (2009). The role of narratives in sustaining organizational innovation. Organization Science, 20(1), 107-117.

Bechky, B. A. (2003). Sharing meaning across occupational communities: The transformation of understanding on a production floor. Organization Science, 14(3), 312-330.

Berger, P. L., \& Luckmann, T. (1966). The social construction of reality: A treatise in the sociology of knowledge (No. 10). Penguin Uk.

Bergström, O., \& Knights, D. (2006). Organizational discourse and subjectivity: Subjectification during processes of recruitment. Human Relations, 59(3), 351-377.

Billig, M. (1996). Arguing and thinking: A rhetorical approach to social psychology, Cambridge University Press, Cambridge.

Boden, D. (1994). The business of talk: Organizations in action. Cambridge: Polity Press.

Brown, A. D., \& Coupland, C. (2005). Sounds of silence: Graduate trainees, hegemony and resistance. Organization Studies, 26(7), 1049-1069.

Brown, J. S., and P. Duguid 1991. 'Organizational learning and communities-of-practice: Towards a unified view of working, learning and innovating'. Organization Science, 2(1): 40-58. 
Brown, A. D., Kornberger, M., Clegg, S. R., \& Carter, C. (2010). 'Invisible walls' and 'silent hierarchies': A case study of power relations in an architecture firm. $\mathrm{Hu}$ man Relations, 63(4), 525-549.

Burr, V. (2015). Social constructionism. Routledge.

Czarniawska, B. (2008). How to misuse institutions and get away with it: Some reflections on institutional theory (ies). The Sage handbook of organizational institutionalism, 769-782.

Clegg, S. R., Pitsis, T. S., Rura-Polley, T., \& Marosszeky, M. (2002). Governmentality matters: designing an alliance culture of inter-organizational collaboration for managing projects. Organization Studies, 23(3), 317-337.

Costas, J., \& Fleming, P. (2009). Beyond dis-identification: A discursive approach to self-alienation in contemporary organizations. Human Relations, 62 (3), 353378.

Covaleski, M. A., Dirsmith, M. W., Heian, J. B., \& Samuel, S. (1998). The calculated and the avowed: Techniques of discipline and struggles over identity in Big Six public accounting firms. Administrative Science Quarterly, 43 (2), 293-327.

Cunliffe, A. L. (2016). "On becoming a critically reflexive practitioner" redux: What does it mean to be reflexive? Journal of Management Education, 40(6), 740746.

Dahl, A., Lawrence, J., \& Pierce, J. (2011). Building an innovation community. Research-Technology Management, 54, 19-27.

Danziger, K. (1997). The varieties of social construction. Theory \& Psychology, 7(3), $399-416$.

Davies, B., \& Harré, R. (1990). Positioning: The discursive production of selves. Journal for the Theory of Social Behavior, 20(1), 43-63.

Denzin, N. K. \& Lincoln, Y. S. (2008). Collecting and interpreting qualitative materials (Vol. 3). Sage.

Deuten, J. J., \& Rip, A. (2000). Narrative infrastructure in product creation processes. Organization, 7(1), 69-93.

van Dijk, C., \& van den Ende, J. (2002). Suggestion systems: transferring employee creativity into practicable ideas. R\&D Management, 32, 387-395.

Doolin, B. (2002). Enterprise discourse, professional identity and the organizational control of hospital clinicians. Organization Studies, 23(3), 369-390.

Dougherty, D. (1992). Interpretive barriers to successful product innovation in large firms. Organization Science, 3(2), 179-202.

Dougherty, D., Borrelli, L., Munir, K., \& O’Sullivan, A. (2000). Systems of organizational sensemaking for sustained product innovation. Journal of Engineering and Technology Management, 17(3-4), 321-355.

Edwards, D., Potter, J., 1992. Discursive psychology. Sage, London.

Eisenhardt, K. M., \& Graebner, M. E. (2007). Theory building from cases: Opportunities and challenges. Academy of Management Journal, 50(1), 25-32.

Ellis, D. G. (1999). Research on social interaction and the micro-macro issue. Research on Language \& Social Interaction, 32(1-2), 31-40.

Ezzamel, M., \& Willmott, H. (1998). Accounting for teamwork: A critical study of group-based systems of organizational control. Administrative Science Quarterly, 358-396.

Ezzamel, M., \& Willmott, H. (2010). Strategy and strategizing: A poststructuralist perspective. In Baum, J. A. \& Lampel, J. (ed.), The globalization of strategy research (Advances in strategic management, Volume 27), Emerald Group Publishing Limited, pp.75-109.

Elsbach, K. D. (1999). An expanded model of organizational identification. In Sutton, R. I. \& Staw, B. M. (Eds.), Research in organizational behavior, Vol. 21, pp. 163-199). US: Elsevier Science. 
Fairbank, J. F., \& Williams, S. D. (2001). Motivating creativity and enhancing innovation through employee suggestion system technology. Creativity and Innovation Management, 10, 68-74.

Fairclough, N. (1992). Discourse and text: Linguistic and intertextual analysis within discourse analysis. Discourse \& Society, 3(2), 193-217.

Fairclough, N. (2005). Peripheral vision: Discourse analysis in organization studies: The case for critical realism. Organization Studies, 26(6), 915-939.

Fleming, P., \& Sewell, G. (2002). Looking for the good soldier, Švejk: Alternative modalities of resistance in the contemporary workplace. Sociology, 36(4), 857-873.

Fleming, P., \& Spicer, A. (2003). Working at a cynical distance: Implications for power, subjectivity and resistance. Organization, 10(1), 157-179.

Fleming, P., \& Spicer, A. (2007). Contesting the corporation: Struggle, power and resistance in organizations. Cambridge University Press.

Fleming, P., \& Spicer, A. (2014). Power in management and organization science. The Academy of Management Annals, 8(1), 237-298.

Freeman, C. (1995). The 'National System of Innovation' in historical perspective. Cambridge Journal of Economics, 19(1), 5-24.

Fougére \& Harding, (2012). On the limits of what can be said about innovation: interplay and contrasts between academic and policy discourses. In Sveiby, K. E., Gripenberg, P., \& Segercrantz, B. (ed.). Challenging the innovation paradigm (pp. 15-36). Routledge.

Ford, J. D. (1999). Organizational change as shifting conversations. Journal of Organizational Change Management, 12, 480-500.

Foucault, Michel. (1972). The archaeology of knowledge. London: Routledge.

Foucault, M. (1977). Discipline and punish: The birth of the prison. London: Penguin.

Foucault, M. (1978). The history of sexuality: An introduction. Vol. 1. New York: Vintage, 208.

Garcia, R., \& Calantone, R. (2002). A critical look at technological innovation typology and innovativeness terminology: a literature review. Journal of Product Innovation Management, 19(2), 110-132.

Garud, R., Gehman, J., Kumaraswamy, A. (2011) Complexity Arrangements for Sustained Innovaiton: Lessons from 3M Corporation, Organization Studies, 32 (6), 737-767.

Garud, R., \& Nayyar, P. R. (1994). Transformative capacity: Continual structuring by intertemporal technology transfer. Strategic Management Journal, 15(5), 365385 .

Gergen, K. J. (1985). The social constructionist movement in modern psychology. American Psychologist, 40(3), 266.

Gertsen, M. C., \& Søderberg, A. M. (2011). Intercultural collaboration stories: On narrative inquiry and analysis as tools for research in international business. Journal of International Business Studies, 42(6), 787-804.

Godin, B. (2012). кaıvotouia: an Old Word for a New World, or the De-contestation of a Political and Contested Concept. In Sveiby, K. E., Gripenberg, P., \& Segercrantz, B. (Eds.). Challenging the innovation paradigm (pp. 37-60). Routledge.

Godin, B. (2015). Innovation: A Study in the Rehabilitation of a Concept. Contributions to the History of Concepts, 10(1), 45-68.

Gotsi, M., Andriopoulos, C., Lewis, M. W., \& Ingram, A. E. (2010). Managing creatives: Paradoxical approaches to identity regulation. Human Relations, 63(6), 781805 .

Goffman, E. (1981), Forms of Talk, Basil Blackwell, Oxford.

Gold, R.L., 1958. Roles in sociological field observations. Sociological Forces, 36, 217223.

Grant, D. (Ed.). (2004). The Sage handbook of organizational discourse. Sage. 
Gripenberg et al (2012). Challenging the innovation paradigm: the prevailing pro-innovation bias. In Sveiby, K. E., Gripenberg, P., \& Segercrantz, B. (Eds.). Challenging the innovation paradigm (pp. 1-12). Routledge.

Halford, S., \& Leonard, P. (2006). Place, space and time: Contextualizing workplace subjectivities. Organization Studies, 27(5), 657-676.

Hall, S. (2001). Foucault: Power, knowledge and discourse. In Wetherell, M, Taylor, S. \& Yates, S. (ed.), Discourse theory and practice: A reader (pp.72-81). Sage Publications.

Hamel, G., \& Ruben, P. (2000). Leading the revolution (Vol. 286). Boston, MA: Harvard Business School Press.

Hardy, C., \& Phillips, N. (2004). Discourse and power. In, Grant, D. (Ed.), The Sage handbook of organizational discourse (pp. 299-316). Sage Publications.

Hardy, C., \& Thomas, R. (2014). Strategy, discourse and practice: The intensification of power. Journal of Management Studies, 51(2), 320-348.

Hasu, M., Leitner, K., Solitander, N. \& Varblane, U. (2012). Accelerating the innovation race: do we need reflexive brakes? In Sveiby, K. E., Gripenberg, P., \& Segercrantz, B. (Eds.). Challenging the innovation paradigm (pp. 87-112). Routledge.

Heracleous, L. (2004). Interpretivist approaches to organizational discourse. In, Grant, D. (Ed.), The Sage handbook of organizational discourse, (pp. 175-192). Sage Publications.

Hodgson, D. (2002). Disciplining the professional: the case of project management. Journal of Management Studies, 39(6), 803-821.

Huhtala, H., \& Parzefall, M. R. (2007). A review of employee well-being and innovativeness: An opportunity for a mutual benefit. Creativity and Innovation Management, 16(3), 299-306.

Humphreys, M., \& Brown, A. D. (2002). Narratives of organizational identity and identification: A case study of hegemony and resistance. Organization Studies, 23(3), 421-447.

Jaussi, K. S., Randel, A. E., \& Dionne, S. D. (2007). I am, I think I can, and I do: The role of personal identity, self-efficacy, and cross-application of experiences in creativity at work. Creativity Research Journal, 19, 247-258.

Jenkins, R. (2014). Social identity. Routledge.

Kimberly, J. R. (1981). Managerial innovation. In P.C. Nystrom \& W.H. Starbuck (ed.), Handbook of organisational design, (pp. 84-104). Oxford University Press.

Knights, D., \& McCabe, D. (2003). Governing through teamwork: Reconstituting subjectivity in a call centre. Journal of Management Studies, 40(7), 1587-1619.

Knights, D., \& McCabe, D. (2000). 'Ain't misbehavin'? Opportunities for resistance under new forms of 'quality'management. Sociology, 34(3), 421-436.

Knights, D., \& Morgan, G. (1991). Corporate strategy, organizations, and subjectivity: A critique. Organization Studies, 12(2), 251-273.

Laine, P. M., Meriläinen, S., Tienari, J., \& Vaara, E. (2016). Mastery, submission, and subversion: On the performative construction of strategist identity. Organization, 23(4), 505-524.

Laine, P. M., \& Vaara, E. (2007). Struggling over subjectivity: A discursive analysis of strategic development in an engineering group. Human Relations, 60(1), 29-58.

Lempiälä, T. (2011). Entering the back stage of innovation: tensions between the collaborative praxis of idea development and its formal staging in organisations. Doctoral dissertation. Aalto University. Department of Management Studies.

Lempiälä, T., Yli-Kauhaluoma, S., \& Näsänen, J. (2018). Similar structures, different interpretations: perceived possibilities for employee-driven innovation in two teams within an industrial organisation. International Journal of Entrepreneurship and Innovation Management, 22(4-5), 362-380.

Lincoln, Y. S., \& Guba, E. G. (1985). Naturalistic inquiry. Beverly Hills, CA: Sage. 
Mantere, S., \& Vaara, E. (2008). On the problem of participation in strategy: A critical discursive perspective. Organization Science, 19(2), 341-358.

McAdam, R., McClelland, J. (2002) Individual and team-based idea generation within innovation management: organizational and research agendas. European Journal of Innovation Management, 5, pp. 86-97.

Marshall, C., \& Rossman, G. B. (1995). Designing qualitative research. Newbury Park: Sage.

Meriläinen, S., Tienari, J., Thomas, R., \& Davies, A. (2004). Management consultant talk: A cross cultural comparison of normalizing discourse and resistance. Organization, 11(4), 539-564.

Morrison, E. W., \& Phelps, C. C. (1999). Taking charge at work: Extrarole efforts to initiate workplace change. Academy of Management Journal, 42, 403-419.

Mumby, D. K., \& Clair, R. P. (1997). Organizational discourse. In T. van Dijk (ed.), Discourse as social interaction: Discourse studies. A multidisciplinary introduction, vol 2, (pp. 181-205). Sage Publications.

Nelson, R. R. (Ed.). (1993). National innovation systems: a comparative analysis. Oxford University Press on Demand.

Nikander, P. (2012). Interviews as discourse data. In J.F. Gubrium, Holstein J.A., Marvasti A.B. \& McKinney K.D. (Ed.), The SAGE handbook of interview research. The complexity of the craft, (s. 397-413). Second edition. London: Sage.

Näsänen, J. (2018). Supporting and contesting organizational change: a discursive study on contradictory visions of a change. Doctoral dissertation. Helsinki University, Department of Social Research.

Oakes, L. S., Townley, B., \& Cooper, D. J. (1998). Business planning as pedagogy: Language and control in a changing institutional field. Administrative Science Quarterly, 257-292.

Ogbor, J. O. (2000). Mythicizing and reification in entrepreneurial discourse: Ideology-critique of entrepreneurial studies. Journal of Management Studies, 37(5), 605-635.

Oldham, G. R., \& Cummings, A. (1996). Employee creativity: Personal and contextual factors at work. Academy of Management Journal, 39, 607-634.

Phillips, N., \& Hardy, C. (2002a). Understanding discourse analysis. Thousand Oaks, CA: Sage.

Phillips, N., \& Hardy, C. (2002b). Discourse Analysis: Investigating the Process of Social Construction. Sage University Papers series On Qualitative Research Methods, Vol. 50. Thousand Oaks, CA: Sage.

Piderit, S. K. (2000). Rethinking resistance and recognizing ambivalence: A multidimensional view of attitudes toward an organizational change. Academy of Management Review, 25(4), 783-794.

Prasad, P., \& Prasad, A. (2000). Stretching the iron cage: The constitution and implications of routine workplace resistance. Organization Science, 11(4), 387-403.

Prichard, C., Jones, D., \& Stablein, R. (2004). Doing research in organizational discourse: The importance of researcher context. In, Grant, D. (Ed.), The Sage handbook of organizational discourse (pp. 213-236). Sage Publications.

Potter, J., \& Wetherell, M. (1987). Discourse and social psychology: Beyond attitudes and behaviour. Sage.

Putnam, L. L., Grant, D., Michelson, G., \& Cutcher, L. (2005). Discourse and resistance: Targets, practices, and consequences. Management Communication Quarterly, 19(1), 5-18.

Reissman, C. K. (1993). Narrative analysis: Qualitative research methods series 30. Sage Publications.

Samra-Fredericks, D. (2003). Strategizing as lived experience and strategists' everyday efforts to shape strategic direction. Journal of Management Studies, 40(1), 141174. 
Sarbin, T. R. (1986). The narrative as a root metaphor for psychology. Praeger Publishers.

Scott, S. G., \& Bruce, R. A. (1994). Determinants of innovative behavior: A path model of individual innovation in the workplace. Academy of Management Journal, $37,580-607$.

Segercrantz, B. (2012). From autonomous craftsmen to compliant resources: implications for undesirable consequences of innovation. In Sveiby, K. E., Gripenberg, P., \& Segercrantz, B. (Eds.). Challenging the innovation paradigm (pp. 186202). Routledge.

Sonenshein, S. (2010). We're Changing-Or are we? Untangling the role of progressive, regressive, and stability narratives during strategic change implementation. Academy of Management Journal, 53(3), 477-512.

Spicer, A., \& Böhm, S. (2007). Moving management: Theorizing struggles against the hegemony of management. Organization Studies, 28(11), 1667-1698.

Sveiby, K. E., Gripenberg, P., \& Segercrantz, B. (2012). The unintended and undesirable consequences: neglected by innovation research. In Sveiby, K. E., Gripenberg, P., \& Segercrantz, B. (Eds.). Challenging the innovation paradigm (pp. 61-84). Routledge.

Symon, G. (2005). Exploring resistance from a rhetorical perspective. Organization Studies, 26(11), 1641-1663.

Thomas, R., \& Davies, A. (2005). Theorizing the micro-politics of resistance: New public management and managerial identities in the UK public services. Organization Studies, 26(5), 683-706.

Thomas, R., \& Linstead, A. (2002). Losing the plot? Middle managers and identity. Organization, 9(1), 71-93.

Thornborrow, T., \& Brown, A. D. (2009). Being regimented': Aspiration, discipline and identity work in the British parachute regiment. Organization Studies, 30(4), 355-376.

Townley, B. (1993). Foucault, power/knowledge, and its relevance for human resource management. Academy of Management Review, 18(3), 518-545.

Trethewey, A. (1997). Resistance, identity, and empowerment: A postmodern feminist analysis of clients in a human service organization. Communications Monographs, 64(4), 281-301.

Eero Vaara, (2010), Taking the linguistic turn seriously: Strategy as A multifaceted and interdiscursive phenomenon, in Baum, J.A.C., Lampel, J. (ed.) The Globalization of Strategy Research (Advances in Strategic Management, Volume 27), (pp.29 - 50). Emerald Group Publishing Limited

Welch, C., \& Piekkari, R. (2017). How should we (not) judge the 'quality'of qualitative research? A re-assessment of current evaluative criteria in International Business. Journal of World Business, 52(5), 714-725.

Whittle, A. (2005). Preaching and practicing 'flexibility': Implications for theories of subjectivity at work. Human Relations, 58(10), 1301-1322.

Ybema, S., Keenoy, T., Oswick, C., Beverungen, A., Ellis, N., \& Sabelis, I. (2009). Articulating identities. Human Relations, 62(3), 299-32. 


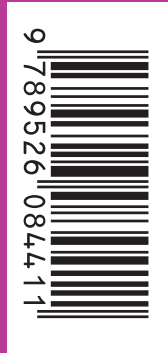

ISBN 978-952-60-8441-1 (printed)

ISBN 978-952-60-8442-8 (pdf)

ISSN 1799-4934 (printed)

ISSN 1799-4942 (pdf)

Aalto University

School of Business

Department of Management Studies

www.aalto.fi

ART +

DESIGN +

ARCHITECTURE

SCIENCE +

TECHNOLOGY

CROSSOVER

DOCTORAL

DISSERTATIONS 